University of Nebraska - Lincoln

DigitalCommons@University of Nebraska - Lincoln

USDA Forest Service / UNL Faculty Publications U.S. Department of Agriculture: Forest Service -National Agroforestry Center

2006

\title{
Wildlife and Invertebrate Response to Fuel Reduction Treatments in Dry Coniferous Forests of the Western United States: A Synthesis
}

\author{
David S. Pilliod \\ Aldo Leopold Wilderness Research Institute, dpilliod@usgs.gov \\ Evelyn L. Bull \\ USDA Forest Service \\ Jane L. Hayes \\ USDA Forest Service \\ Barbara C. Wales \\ USDA Forest Service
}

Follow this and additional works at: https://digitalcommons.unl.edu/usdafsfacpub

Part of the Forest Sciences Commons

Pilliod, David S.; Bull, Evelyn L.; Hayes, Jane L.; and Wales, Barbara C., "Wildlife and Invertebrate Response to Fuel Reduction Treatments in Dry Coniferous Forests of the Western United States: A Synthesis" (2006). USDA Forest Service / UNL Faculty Publications. 63.

https://digitalcommons.unl.edu/usdafsfacpub/63

This Article is brought to you for free and open access by the U.S. Department of Agriculture: Forest Service -National Agroforestry Center at DigitalCommons@University of Nebraska - Lincoln. It has been accepted for inclusion in USDA Forest Service / UNL Faculty Publications by an authorized administrator of DigitalCommons@University of Nebraska - Lincoln. 
Pilliod, David S.; Bull, Evelyn L.; Hayes, Jane L.; Wales, Barbara C. 2006. Wildlife and invertebrate response to fuel reduction treatments in dry coniferous forests of the Western United States: a synthesis. Gen. Tech. Rep. RMRS-GTR-173. Fort Collins, CO: U.S. Department of Agriculture, Forest Service, Rocky Mountain Research Station. 34 p.

\section{Abstract}

This paper synthesizes available information on the effects of hazardous fuel reduction treatments on terrestrial wildlife and invertebrates in dry coniferous forest types in the West. We focused on thinning and/or prescribed fire studies in ponderosa pine (Pinus ponderosa) and dry-type Douglas-fir ( $P$ seudotsuga menziesii), lodgepole pine (Pinus contorta), and mixed coniferous forests. Overall, there are tremendous gaps in information needed to evaluate the effects of fuel reduction on the majority of species found in our focal area. Differences among studies in location, fuel treatment type and size, and pre- and post-treatment habitat conditions resulted in variability in species responses. In other words, a species may respond positively to fuel reduction in one situation and negatively in another. Despite these issues, a few patterns did emerge from this synthesis. In general, fire-dependent species, species preferring open habitats, and species that are associated with early successional vegetation or that consume seeds and fruit appear to benefit from fuel reduction activities. In contrast, species that prefer closed-canopy forests or dense understory, and species that are closely associated with those habitat elements that may be removed or consumed by fuel reductions, will likely be negatively affected by fuel reductions. Some habitat loss may persist for only a few months or a few years, such as understory vegetation and litter that recover quickly. The loss of large-diameter snags and down wood, which are important habitat elements for many wildlife and invertebrate species, may take decades to recover and thus represent some of the most important habitat elements to conserve during fuel reduction treatments. Management activities that consider the retention of habitat structures (such as snags, down wood, and refugia of untreated stands) may increase habitat heterogeneity and may benefit the greatest number of species in the long run.

Key words: dry coniferous forests, fuel reduction, habitat, invertebrates, prescribed fire, thinning, Western United States, wildlife

\section{The Authors}

David S. Pilliod was a post-doctoral Ecologist with the USDA Forest Service, Rocky Mountain Research Station at the Aldo Leopold Wilderness Research Institute in Missoula, MT. He is currently an Assistant Professor in the Department of Biological Sciences, College of Science and Mathematics at California Polytechnic State University in San Luis Obispo, CA.

Evelyn L. Bull is a Research Wildlife Biologist, Jane L. Hayes is a Research Biological Scientist, and Barbara C. Wales is a Wildlife Biologist with the USDA Forest Service, Pacific Northwest Research Station in La Grande, OR.

Cover inset photo: Black-backed woodpecker. Photo by Evelyn Bull.

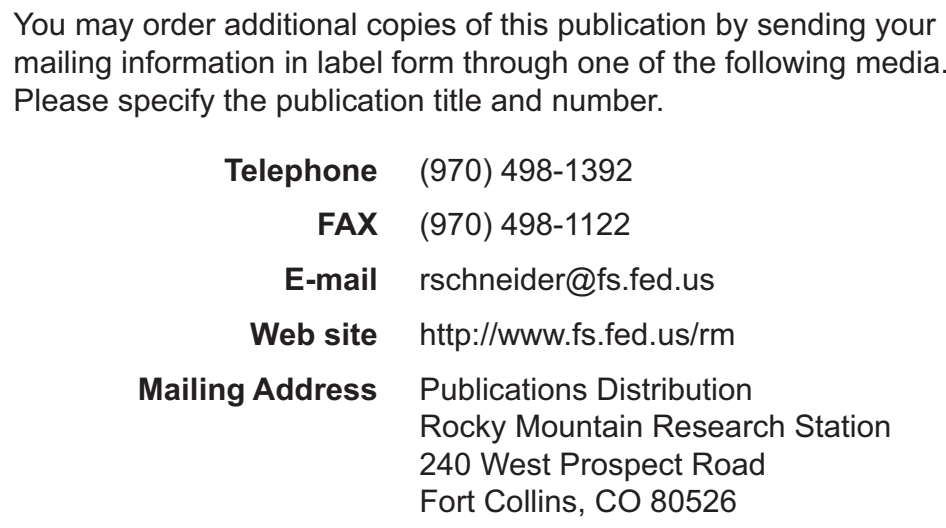




\section{Wildlife and Invertebrate Response to Fuel Reduction Treatments in Dry Coniferous Forests of the Western United States: A Synthesis}

\section{Foreword}

This document is part of the Fuels Planning: Science Synthesis and Integration Project, a pilot project initiated by the USDA Forest Service to respond to the need for tools and information useful for planning site-specific fuel (vegetation) treatment projects. The information addresses fuel and forest conditions of the dry inland forests of the Western United States: those dominated by ponderosa pine, Douglas-fir, dry grand fir/white fir, and dry lodgepole pine potential vegetation types. Information was developed primarily for application at the stand level and is intended to be useful within this forest type regardless of ownership. Portions of the information also will be directly applicable to the pinyon pine/juniper potential vegetation types. Many of the concepts and tools developed by the project may be useful for planning fuel projects in other forests types. In particular, many of the social science findings would have direct applicability to fuel planning activities for forests throughout the United States. As is the case in the use of all models and information developed for specific purposes, our tools should be used with a full understanding of their limitations and applicability.

The science team, although organized functionally, worked hard at integrating the approaches, analyses, and tools. It is the collective effort of the team members that provides the depth and understanding of the work.
The science team leadership included the following USDA Forest Service personnel:

- Deputy Science Team Leader Sarah McCaffrey, North Central Research Station

- Forest structure and fire behavior: Dave Peterson and Morris Johnson, Pacific Northwest Research Station

- Environmental consequences: Elaine Kennedy Sutherland and Anne Black, Rocky Mountain Research Station

- Economic uses of materials: Jamie Barbour and Roger Fight, Pacific Northwest Research Station

- Public attitudes and beliefs: Pamela Jakes and Susan Barro, North Central Research Station

- Technology transfer: John Szymoniak, Pacific Southwest Research Station

This project would not have been possible were it not for the vision and financial support of USDA Forest Service, Washington Office Fire and Aviation Management individuals, Janet Anderson, and Leslie Sekavec.

Russell T. Graham, Science Team Leader USDA Forest Service, Rocky Mountain Research Station
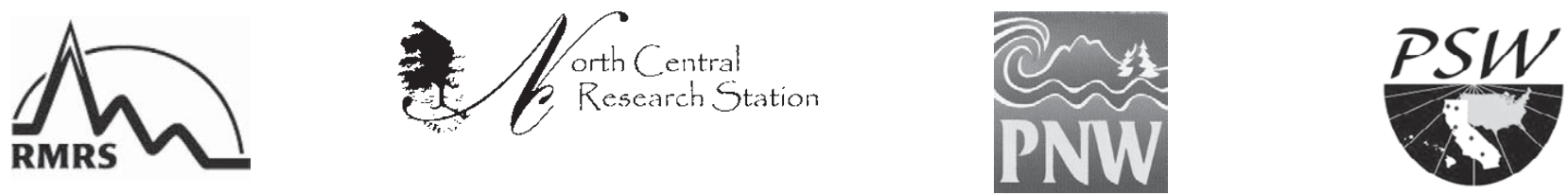


\section{Acknowledgments}

Part or all of the manuscript was reviewed by Rick Brown, James LaBonte, Kim Mellen, Victoria Saab, Lia Spiegel, Elaine Kennedy Sutherland, Christina Vojta, and an anonymous reviewer. Wildlife sketches were done by Susan Lindstedt. 


\section{Contents}

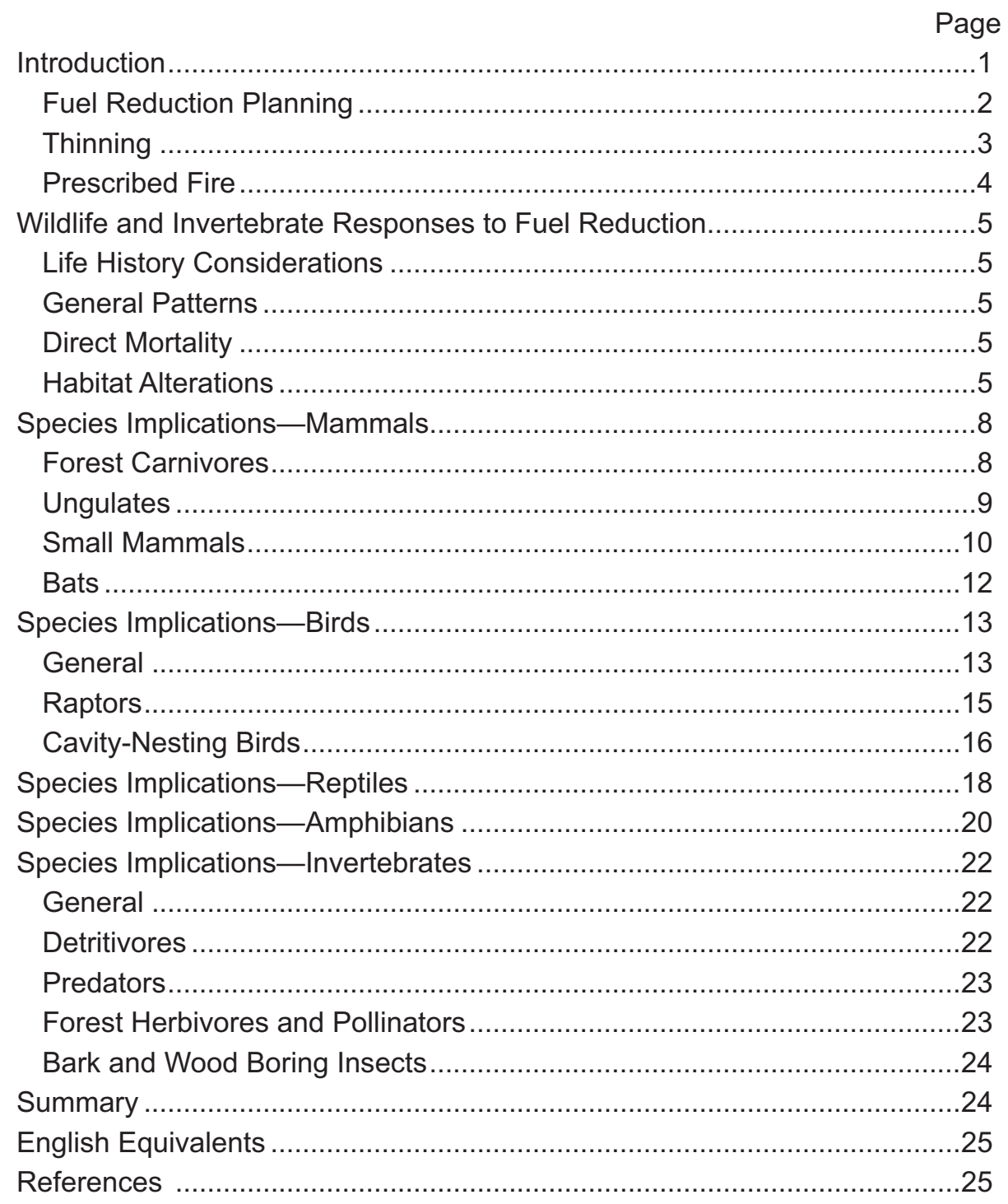




\section{Wildlife and Invertebrate Response to Fuel Reduction Treatments in Dry Coniferous Forests of the Western United States: A Synthesis}

\author{
David S. Pilliod \\ Evelyn L. Bull \\ Jane L. Hayes \\ Barbara C. Wales
}

\section{Introduction}

The National Fire Plan (USDA and USDI 2001) and the Healthy Forest Restoration Act (HFRA 2003) mandate federal land managers to restore forest habitats and to reduce risk of wildfire on federal lands, particularly along the wildlandurban interface. Restoration may include reducing fuels and may allow fire back into fire-dependent systems. To reduce the intensity and spread of fire, federal land managers are reducing hazardous fuels primarily by using thinning (selective cutting) or prescribed fire or a combination of the two (Graham and others 2004; USDA 2003). Hazardous fuels are generally considered to be standing and down dead wood, tall shrubs, and small trees-forest biomass that has accumulated as a result of many factors, including prior land use (for example, cattle grazing, which removed fine fuels that once carried frequent understory fires) and successful fire exclusion programs (Covington and Moore 1994; Peterson and others 2005).

Part of the planning process for fuel reduction projects is an environmental assessment of potential impacts under the National Environmental Policy Act (NEPA 1969) and the National Forest Management Act (NFMA 1976). Sustaining viable populations of terrestrial fauna is generally accomplished by maintaining habitat. Because populations are associated with the structure and composition of living and dead vegetation, there is little doubt that fuel reduction projects will affect habitats in some way.

Fire regimes in dry coniferous forests of the West have been characterized as historically having low-intensity fires at frequent intervals over small to moderate spatial scales (Agee 1993). These forests were often described as park-like by early explorers and settlers. Lightning-ignited fires carried on the surface killed small trees and top-killed shrubs, but did not kill large fire-tolerant trees like ponderosa pine (Pinus ponderosa) and Douglas-fir (Pseudotsuga menziesii) (DeBano and others 1998). Dry lodgepole pine (Pinus contorta) and other more moist higher elevation forests likely burned over larger spatial scales, at higher intensity, and less frequently than ponderosa pine forests (Agee 1993). Current forest structural characteristics resulted from fire exclusion, timber harvesting, and domestic livestock grazing (Covington and Moore 1994; Peterson and others 2005). Conditions today are different from those developed under natural disturbance regimes; present conditions include large patches with high stand densities, complex stand structure, more fire-intolerant species, and greater fuel accumulations (Graham and others 2004; Peterson and others 2005). Hence, fuel reduction treatments should gradually result in favorable conditions for species that thrive in low-intensity, moderateto high-frequency disturbances and less complex structure (DeBano and others 1998). It is probable that those species that use a mosaic of disturbed and undisturbed forest stands for reproduction, foraging, and cover may benefit from fuel treatments whereas other species that are associated with large patches of high density trees and more complex structure may lose habitat through fuel treatments.

The goal of this paper is to provide information to help fuel planners, fire managers, and NEPA specialists evaluate the potential effects of thinning and prescribed fire on terrestrial vertebrate and invertebrate species and their habitats in the dry coniferous forests of the Western United States. The forest types that we consider are predominantly ponderosa pine and Douglas-fir, and the drier sites containing lodgepole pine, grand fir (Abies grandis), incense-cedar (Calocedrus decurrens), western larch (Larixoccidentalis), and sugar pine (Pinus lambertiana) (Hann and others 1997), and occurring in Washington, Oregon, Idaho, Montana, California, Nevada, 
Utah, Wyoming, South Dakota, Colorado, New Mexico, and Arizona (fig. 1). This document is not an exhaustive review; rather, we present studies representative of the available literature on fuel reduction effects. We include some wildland fire or commercial logging studies. Where data are limited for our subject, we also present and discuss research results from other areas or for other forest types, but these data may or may not apply to dry coniferous forests in the West.

\section{Fuel Reduction Planning}

Determination of a fuel reduction strategy depends on many factors, including defining the desired future conditions of the posttreatment stand characteristics, while recognizing social values and commitments and considering existing and future ecological conditions (Peterson and others 2005; Wissmar and Beschta 1998). Under the Data Quality Act (OMB 2001), fuel planners are required to use the best available data to set objectives for fuel reduction projects, evaluate potential consequences, and determine alternatives. However, the amount and kind of background information available for most treatments and access to that information is often a limitation to this process. New tools are being developed to assist managers in evaluating the social, economic, and ecological consequences of different fuel treatments (see Web site: http://forest.moscowfsl.wsu.edu/fuels/).

The spatial and temporal scale of individual treatments and treatment regimes in a stand or on a landscape are critical to understanding the potential influences of fuel reduction effects on wildlife. In most circumstances, maintaining habitat heterogeneity conserves biodiversity (August 1983; Lassau and Hochuli 2004; Lassau and others 2005). Therefore, fuel specialists may want to work directly with biologists to plan treatments such that, over years and decades, a mosaic of forest structures and conditions which mimic natural disturbance patterns are created, which might be more likely to support greater species diversity than large, homogeneous stands given the same treatment (Allen and others 2002; Morris 1975; Mutch 1970; Nitschke 2005; Potter and Kessell 1980). Treating fuels in habitat patches adjacent to untreated patches that are occupied by a given species may increase the rate of colonization and recovery as compared to restoring areas at random (Huxel and Hastings 1999). Large-scale prescribed fires and thinning are still experimental tools in ecological restoration (box 1), and unanticipated effects on biodiversity, wildlife and invertebrate populations, and ecosystem function may yet be discovered (Allen and others 2002; Carey and Schumann 2003).

On which species should managers focus? Most fuel plans will focus effects assessments on species listed by the U.S. Fish and Wildlife Service or individual states as threatened, endangered, or of conservation concern and species ranked under the Natural Heritage Program system (Biodiversity Network element ranking system, Master 1991). If there is convincing evidence that a listed or proposed species or its critical habitat could be adversely affected by a project, a biological assessment is usually completed to provide supporting documentation during formal consultation with resource agencies. If a listed species is not likely to be adversely affected by a project, a biological evaluation can be used as a basis of information during informal consultation. Consultation culminates a biological opinion that determines whether an action is likely to jeopardize a listed species. New federal policies, such as the 2005 NFMA National Forest Planning Regulations and the 2003 HFRA, enable managers to avoid lengthy assessments if management actions are considered to not adversely affect federally listed species. National Forests are "to provide a framework to contribute to sustaining native ecological systems by providing ecological conditions to support diversity of native plant and animal species in the plan area" (USDA 2005).

A problem with many assessments of potential treatment effects on fauna is that information on how animals respond to fuel reduction is generally lacking. Furthermore, some of the available information on treatment effects on species is ambiguous owing to the difficulty in setting up valid field experiments and the natural variability that exists in animal populations. Variability among sites and past management history also influence effects of treatments. Unfortunately, many of the studies of prescribed fire have been plagued by methodological problems and thus have given few insights into the effects on wildlife (Finch and others 1997; Mantgem and others 2001; Russell and others 1999). When information is unavailable or ambiguous, it can be difficult to know how to proceed with a planned treatment. The Wildlife Habitat Response Model, which uses species-habitat relationships to predict effects of fuel reduction on wildlife habitats, is a tool that may aid in this evaluation process (Pilliod and others, in press).

\section{What is ecological restoration?}

"Ecological restoration is an intentional activity that initiates or accelerates ecosystem recovery with respect to its health (functional processes), integrity (species composition and community structure), and sustainability (resistance to disturbance and resilience). Restoration attempts to return an ecosystem to its historic trajectory, i.e., to a state that resembles a known prior state or to another state that could be expected to develop naturally within the bounds of the historic trajectory (also called 'natural range of variability'). The restored ecosystem may not necessarily recover its former state, since contemporary constraints and conditions can cause it to develop along an altered trajectory."

-Adapted from Clewell and others (2005). Ecological Restoration Society International: Guidelines for developing and managing ecological restoration projects, $2^{\text {nd }}$ edition. 
Wiestern Forest

$\square$ Douglas - fir
$\square$ Hemlock- Sitka spruoe
$\square$ Ponderosa pine
$\square$ Wuestern white pine
$\square$ Lodgepole pine
$\square$ Lareh
$\square$ Fir-spruce
$\square$ Redwood
$\square$ Chaparral
$\square$ Pinyon-juniper
$\square$ Milestern hardmoods

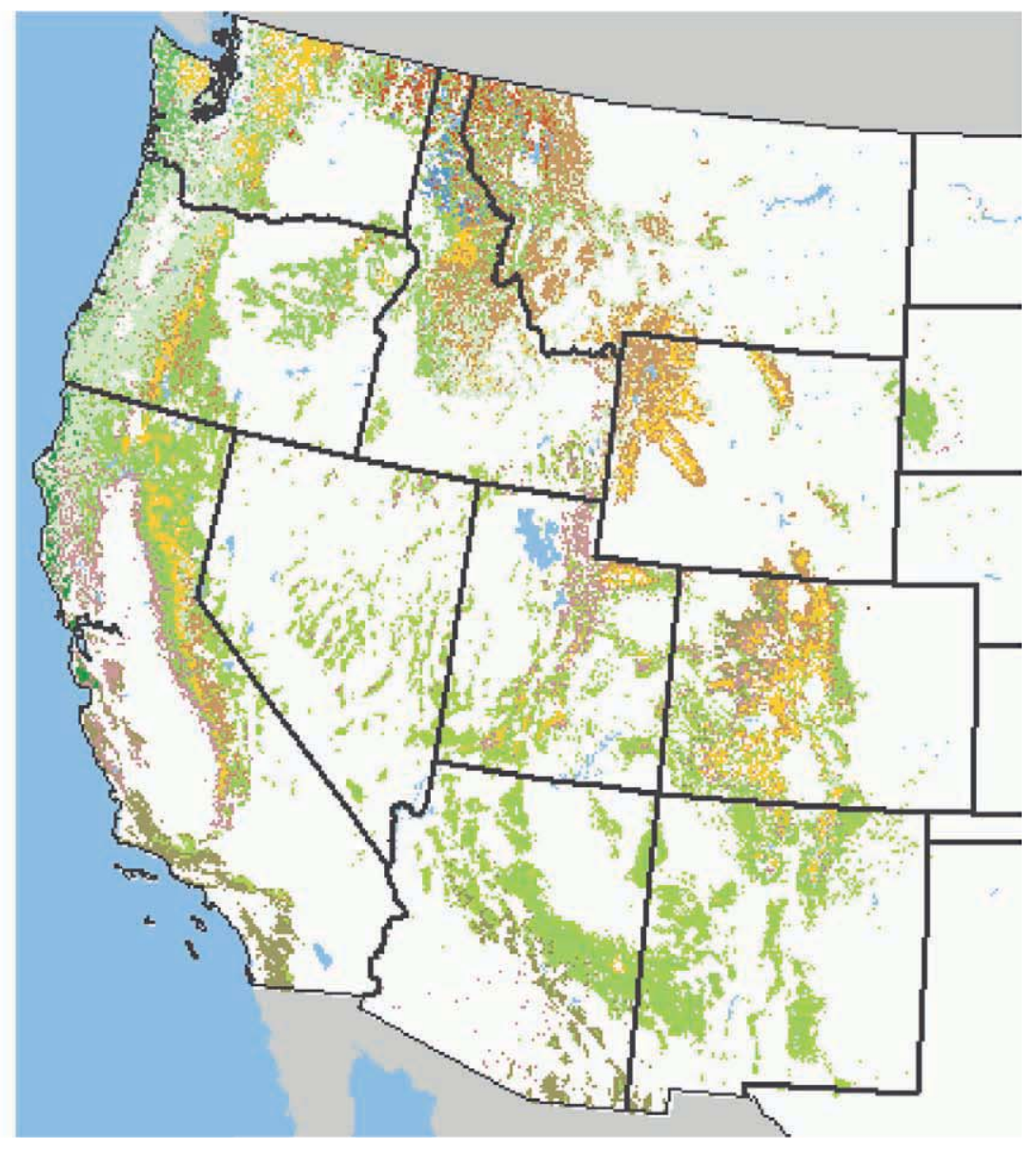

Figure 1-Forest cover types of the western United States. National Atlas of the United States, March 5, 2003, http://nationalatlas.gov

\section{Thinning}

The objective of thinning in fuel reduction treatments is usually to prevent or slow the spread of crown fire by reducing surface and ladder fuels, raising crown base height, and breaking canopy continuity (Graham and others 2004; Pollet and Omi 2002). There is considerable variation in thinning techniques, including the number and size of trees removed, amount and sizes of snags and down wood retained, size and distribution of unthinned patches within the stand, thinning technique (mechanical or hand), and treatment of slash (lop and scatter, pile and burn, chip, or broadcast burn) (Peterson and others 2005). The general definition of thinning in this synthesis is a reduction in the density of understory trees through the removal of selected trees and shrubs. We rarely refer to the specific thinning prescription in discussing thinning effects. For the most part, this paper does not address precommercial thinning in the more traditional sense of a silvicultural treatment done to reduce stand density of young even-aged trees to improve growth of residual trees for later harvest.

Thinning may be more appropriate than prescribed fire where understory trees are so large or dense that attempts to kill them with fire would run a high risk of also killing overstory trees (Brown 2000). One advantage of thinning over fire is that a chainsaw or harvester can provide more control over which trees are actually killed. In addition, down wood and standing dead trees (hereafter snags), which are important wildlife habitat, can more assuredly be retained with thinning than with fire. However, to accomplish fuel treatment objectives, it is likely there will be some reduction in snags and down wood in most operations. 


\section{Prescribed Fire}

The objective of prescribed fire in fuel reduction treatments is to reduce surface and ladder fuels by eliminating live and dead understory vegetation, including down wood (Graham and others 2004). In this synthesis, reference to prescribed fire is either broadcast burning of activity fuels (slash) after thinning or understory burning without thinning. Variation in the severity of the burn influences residual stand characteristics, including the spatial distribution and availability of litter, down wood, snags, and vegetation (Jain and others 2004) (fig. 2). In most cases, prescribed fire results in increased structural complexity and habitat heterogeneity. However, multiple entries with prescribed fire (repeated burning), which is often the only way to reduce fuels effectively without thinning, may reduce the structural complexity of forests over time. Large prescribed fires (greater than $1000 \mathrm{ha}$ ) could also potentially homogenize the landscape for some species and decrease overall wildlife habitat (Brown and others 2004).

The season when prescribed fires are conducted has important consequences for wildlife and invertebrates (King and others 1998). Whereas spring burns may remove grasses and shrubs that provide critical forage and cover for small mammals, birds, ungulates, and invertebrates, late summer and fall burns remove senescent plant biomass and usually stimulate growth of grass and shrubs the following spring (Mushinsky and Gibson 1991; Potter and Kessell 1980). Some spring burns are conducted prior to green-up and many grasses, forbs, and some shrubs will sprout or resprout within a few weeks of a spring fire. Fall fires tend to burn hotter and consume more of the down wood and snags. Stands generally have a range of tree sizes, and it is the smaller diameter trees that will most likely be killed by prescribed fire. These dead trees may provide temporary foraging habitat for some species, such as bark and wood-boring beetles and woodpeckers that feed on them, but these trees are usually too small for nest cavities. Mortality of live trees tends to be less with spring burns than with fall burns owing to higher moisture content in spring. Consumption of large logs by fire is regulated by fuel moisture, which is often higher in spring and may minimize the loss of these important habitat elements compared to fall burns.
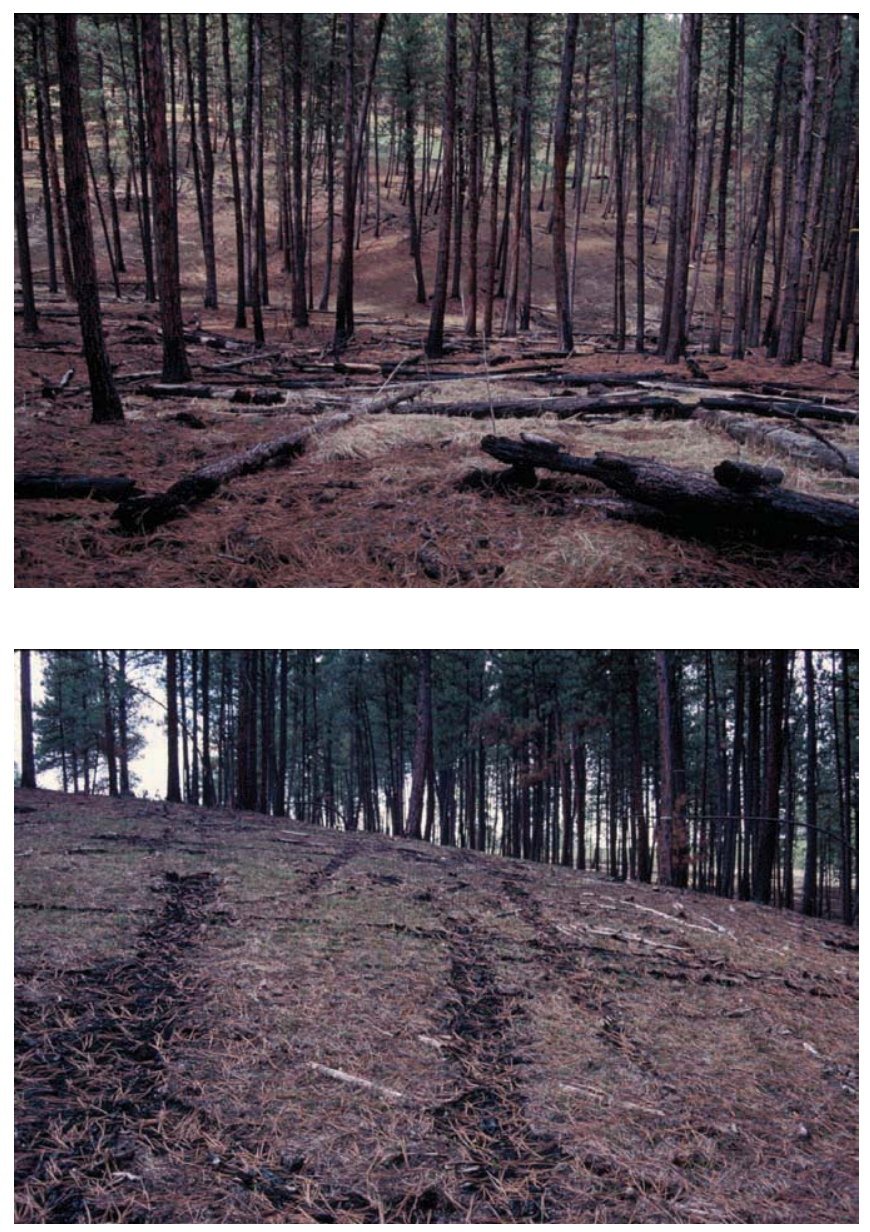

Figure 2-An example of a prescribed fire that resulted in the retention of down wood providing cover for small mammals and foraging substrates for black bears and pileated woodpeckers (top). An example of a prescribed fire that resulted in a loss of all down wood (bottom). Photos by Evelyn Bull. 


\section{Wildlife and Invertebrate Responses to Fuel Reduction}

\section{Life History Considerations}

The potential effects of fuel reduction on a species should be considered within the context of species distribution and abundance, migratory and dispersal characteristics, habitat associations, and potential responses to changes in habitat. If a species is broadly distributed regionally, then local effects in a project area may be relatively inconsequential to population viability depending on a species' ability to recolonize from surrounding areas. However, a species with a limited distribution warrants special consideration. For example, an entire population of a rare species may be contained within a stand being treated and protection for specific habitat components or creation of refugia may be needed. The habitat needs of a species include characteristics important for breeding, producing and rearing of young, feeding, refuge from predators, and protection from adverse environmental conditions. The habitat requirements of some species may be contained within the project area, but other species may use the project area for only part of the year or part of their life cycle. A species' response to habitat changes from fuel reduction depends on what habitat elements are needed for its survival and reproduction, and how these habitat elements are affected by fuel reduction (George and Zack 2001).

\section{General Patterns}

Our knowledge of the effects of different fuel reduction techniques on most wildlife and invertebrate species is limited. Some useful information can be applied from wildfire research and much of this information has been summarized (Fisher and Wilkinson 2005; Kramp and others 1983; Lyon and others 1978; Pilliod and others 2003; Saab and Powell 2005; Smith 2000). Two ongoing broad-scale research studies will provide information on wildlife and invertebrate effects of fuel reduction in the future. The Fire and Fire Surrogate (FFS) project is a long-term study designed to understand the effects of alternative methods for fuel reduction and forest restoration at 13 study sites across the United States (www. fs.fed.us/ffs/). The Birds and Burns Network is investigating the ecological consequences of fire management on wildlife populations, with an emphasis on cavity-nesting birds, in ponderosa pine forests in eight states across the interior West (www.rmrs.nau.edu/lab/4251/birdsnburns/).

\section{Direct Mortality}

Overall, direct mortality of wildlife owing to crushing from heavy equipment, incineration, or asphyxiation during fuel reduction is considered to be low (Folk and Bales 1982), but this is mostly based on anecdotal information. It is believed that most species are able to find refuge microsites (for example, inside burrows or under surface objects) or move away from approaching equipment, heat, or smoke
(Komarek 1969). However, spring-season prescribed fire and thinning during the breeding season may result in mortality of ground-and shrub-nesting bird nestlings and species living within litter such as small mammals, reptiles, amphibians, and invertebrates. Although fires are more likely to kill slowmoving animals (for example, tortoises) that are unable to find refugia quickly (Esque and others 2003; Folk and Bales 1982), or animals that are physiologically compromised (Means and Campbell 1981), even mobile species like birds and large mammals are occasionally killed in fires (Horton 1929). Mortality may be particularly high for many invertebrates (Komarek 1969). Therefore, it should be recognized that a planned burn will likely kill some individuals and that mortality can be significant for some populations. For example, after a roadside burn in Florida, 42 percent (24 of 57 ) of eastern glass lizards (Ophisaurus ventralis) found in a 3-m transect were dead (Babbitt and Babbitt 1951), and in Australia, 29 percent of marked lizards were killed in a late-season burn (Griffiths and Christian 1996).

\section{Habitat Alterations}

In general, if an animal is not killed during a fuel treatment, it will undoubtedly respond to changes in environmental and habitat conditions. Animal responses to environmental change often vary and depend upon characteristics of both the animal and the disturbance (or in this case treatment). Therefore, it is difficult to generalize about the potential effects of fuel reduction on individual species, much less groups of species (for example, small mammals or invertebrate predators). However, it is relatively safe to assume that the wildlife and invertebrate species most likely to be negatively affected by fuel reduction treatments are those depending on the structural features of the fuels being removed (table 1). Wildlife and invertebrate species that depend on down wood, snags, dwarf mistletoe (Arceuthobium spp.) brooms, dense forests with abundant saplings and small poles, and closed canopy-forests for survival and reproduction are likely to be detrimentally affected by fuel treatments that alter these habitat elements. In contrast, species that are associated with fairly open canopies and open forest floor may benefit from fuel treatments. Another consideration is that species responses may vary over time. For example, a small mammal species that needs high shrub cover to avoid predators may do poorly for the first few years posttreatment, but then exceed pretreatment population levels when shrubs recover and food resources are high from increased light, herbaceous growth, and seed production. In addition, an altered vertical structure and decreased tree density may be confounded by secondary effects such as changes in rates of predation, parasitism or interspecific competition which further complicates our abilities to predict overall restoration effects on species distribution and abundance (Chambers and Germaine 2003).

Some wildlife species respond more to vegetation structure than to composition (George and Zack 2001), and the immediate effect of fuel reduction will be a change in the structure of vegetation. For example, the removal of shrubs 
Table 1-Structural features of wildlife and invertebrate habitats altered by fuel reduction treatments.

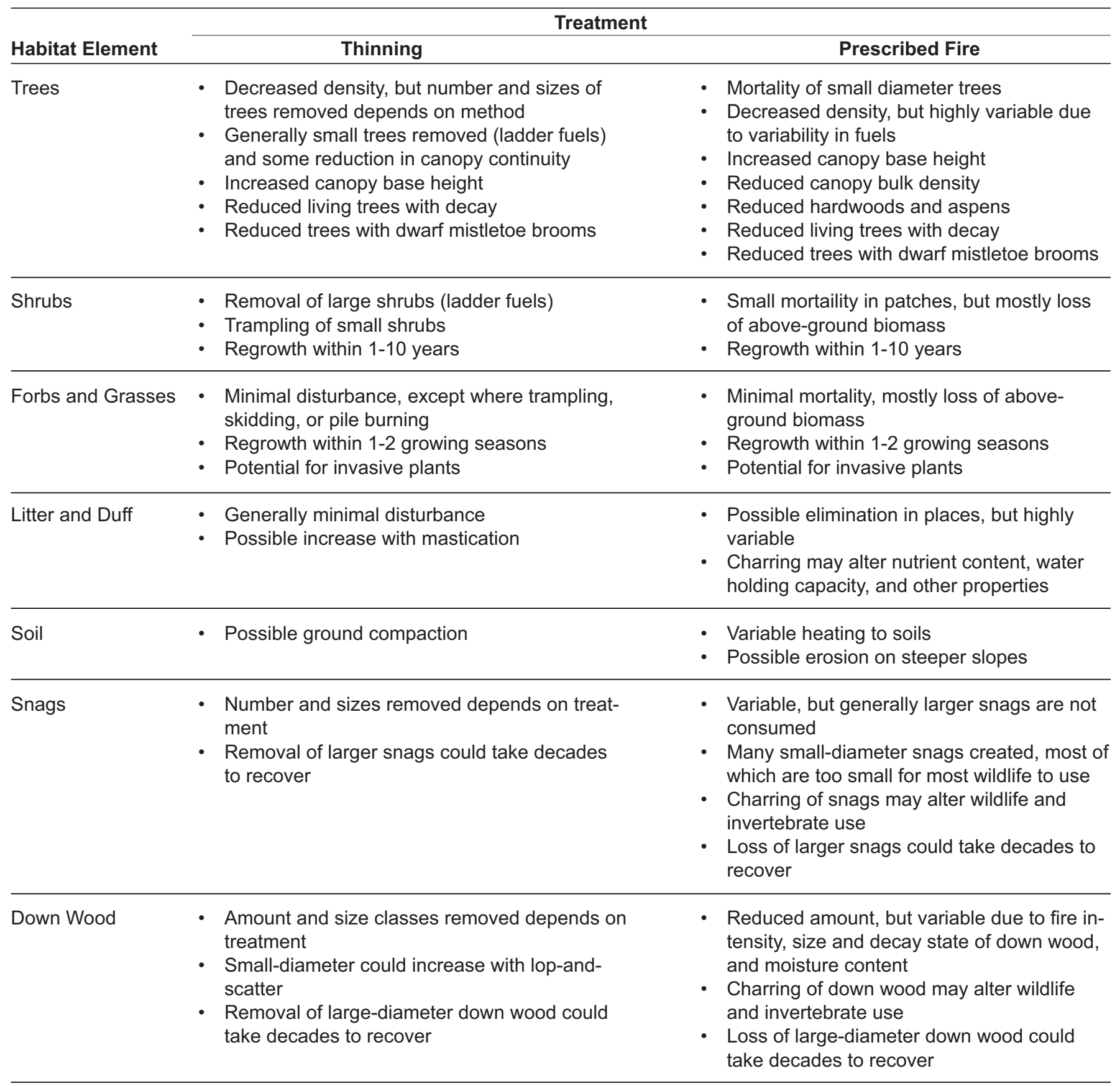


and small trees increases the height to the crown base and eliminates one or more levels of vegetation structure. Over longer timescales, repeated thinning or prescribed fire or both can change the vegetation composition, particularly of shrub and forb species. This change is usually the result of increased light reaching the forest floor and thus altering growing conditions for understory species (Hayes and others 1997). Understory vegetation can also be inhibited by nonnative plants that colonize recently disturbed areas such as might occur after fuel treatments (Brown and Smith 2000; Parks and others 2005). Grazing by both domestic and wild ungulates can also influence understory plant responses to fuel treatments (Dwire and others 2006; Huffman and Moore 2003, 2004). Protecting understory vegetation from overgrazing by domestic animals (for example, cows and sheep) may be important for the first one to two years posttreatment to allow full recovery of herbaceous biodiversity and biomass (Allen and others 2002; Belsky and Blumenthal 1997).

Implementation of any thinning or prescribed burning is likely to result in loss of snags, future snags, and down wood that are important stand attributes of healthy forests and critical components of wildlife and invertebrate habitat (fig. 3). The retention and protection of snags during treatments could minimize the effects of fuel reduction treatments on cavity-dependent wildlife, and retaining some down wood in treated stands could minimize negative effects on species that depend heavily on this habitat structure. Loss of largediameter snags and down wood can take years to decades to recover, as indicated by wildland fire research (Passovoy and Fule 2006). The Healthy Forest Restoration Act (2003) directs "to maximize the retention of large trees," although it is unclear if this includes both live and dead trees.

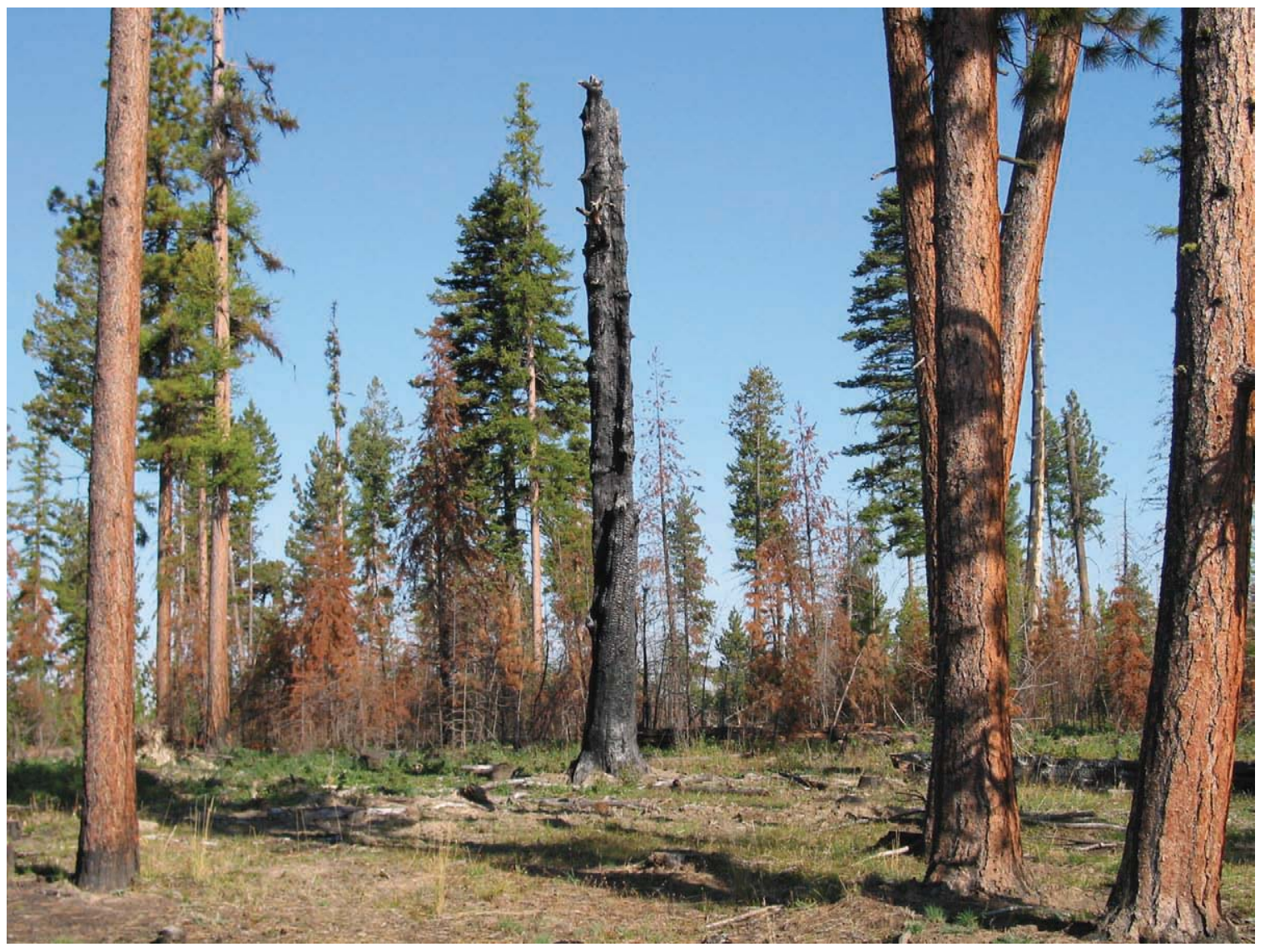

Figure 3-Snag previously used as a nest/roost for pileated woodpeckers inadvertently burned during prescribed fire. Photo by Evelyn Bull. 


\section{Species Implications- Mammals}

\section{Forest Carnivores}

Forest carnivores are generally rare on the landscape, and there are substantial gaps in data on the response of these species to fire and tree harvest (Fisher and Wilkinson 2005). Because most forest carnivores have relatively large activity areas, few species will be affected by fuel reduction at the project or stand level, but could be affected by loss of denning habitat and changes in prey populations due to the cumulative effects of past management, past disturbances, and broad scale implementation of fuel reduction projects. The primary forest carnivores that occur in the dry coniferous forests in the West are the mountain lion (Felis concolor), bobcat (Lynx rufus), wolf (Canis lupus), coyote (Canis latrans), black bear (Ursus americanus), grizzly bear (Ursus arctos horriblis), fisher (Martes pennanti), and American marten (Martes americana). Wolverine (Gulo luscus) and lynx (Lynx canadensis) may occasionally wander through dry forest types but generally inhabit cooler coniferous forests at higher elevations. Although American marten are primarily associated with older forests of Engelmann spruce (Picea engelmannii) and subalpine fir (Abies lasiocarpa), in northeastern Oregon they occasionally occur in drier stands of grand fir and lodgepole pine where they are associated with high densities of down wood and snags (Bull and others 2005c). In this synthesis, we report in detail on black bears because they are common inhabitants of dry forests across our focal area and their diet and habitat use may be influenced by fuel reduction.

Black bears use areas with abundant down wood and dense thickets of shrubs and smaller trees adjacent to or within mature forests (Bull and others 2001a). By volume, around 25 percent of black bear diet can consist of insects (mainly ants [Camponotus spp., Lasius sp., Tapinoma sp., Aphaenogaster sp., Formica spp.] and yellowjackets [Vespula spp., Dolichovespula sp.]) obtained primarily from down logs (Bull and others 2001b). A decrease in down wood would result in fewer ants and yellowjacket nests available to black bears. Black bears are also known to strip the bark from smaller trees and feed on sapwood. In a western larch (Larix occidentalis), lodgepole pine, and Engelmann spruce forest in northwestern Montana, black bear feeding on sapwood was at least five times higher in thinned stands where bears mostly selected larch trees 10 to $20 \mathrm{~cm}$ diameter at breast height (dbh) compared with adjacent unthinned stands (Mason and Adams 1989). It is unclear why bears were attracted to the thinned stand, but health and condition of residual trees may have attracted the bears. Treated stands may also provide dependable food sources for bears, such as when fruit, mast, grass, and herbaceous plant production increases after prescribed fire (Hamilton 1981; Johnson and Landers 1978).

Fuel reduction may decrease the amount of escape cover, which may be the most critical component of black bear habitat (Hamilton 1981). Sites used by black bears for traveling and resting typically have high stem density and dense canopy closure, presumably for security (Bull and others 2001a). A radio-telemetry study of 14 black bears in the ponderosa pine and mixed conifer forests on the Mogollon Rim in northcentral Arizona found that horizontal cover was important for feeding and particularly bedding sites, and that only 12 percent of bedding sites were in areas that had been selectively logged or thinned in the previous 20 years (Mollohan and others 1989). Bears use large-diameter hollow logs for denning (Bull and others 2000) that may be consumed in prescribed fires (fig. 4) or by thinning operations.

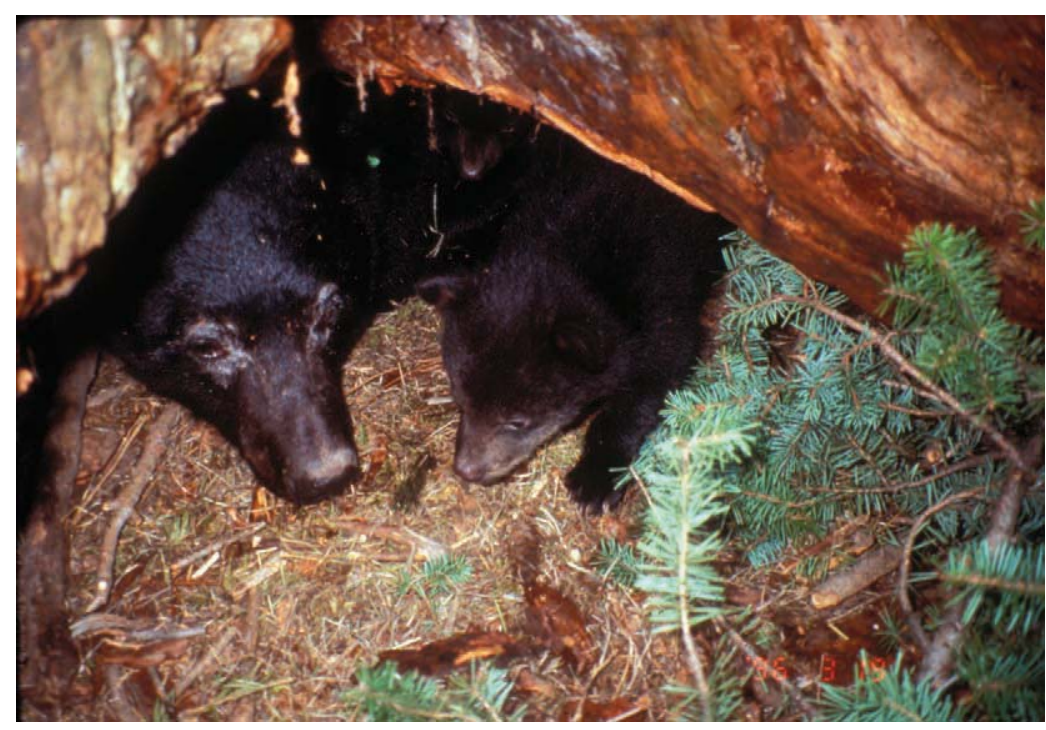

Figure 4-Thinning and prescribed fire will likely increase the amount of grasses and berries used by black bears for foraging but may decrease the amount of hiding cover, den sites in hollow logs, and down wood used for foraging on ants and wasps. Photo courtesy of Oregon Department of Fish and Wildlife. 


\section{Ungulates}

North American ungulates, including deer (Odocoileus spp.), elk (Cervus canadensis), moose (Alces alces), mountain goats (Oreamnos americanus), and bighorn sheep (Ovis canadensis), are generally associated with a mosaic of open areas used for foraging and forested areas used for cover. Some ungulates use dense thickets of shrubs and trees as thermal cover and as cover to hide from predators, for daybeds, and for fawning. All species are associated with areas of abundant forage, such as grasses, forbs, and shrubs. The proximity of these two habitats is important. In Douglas-fir and mixed conifer forests in western Montana, elk generally remain within $200 \mathrm{~m}$ of foraging areas during summer (Edge and others 1987). Thinning alone or combined with prescribed fire will likely increase forage quantity and quality for elk and other ungulates (Demarais and Krausman 2000; Huffman and Moore 2004; McConnell and Smith 1970; Reynolds 1962) (fig. 5). However, retaining patches (at least 0.04 ha) of dense cover (greater than 40 percent closure of midstory canopies) is beneficial for providing security and escape cover for mule deer (O. hemionus) (Chambers and Germaine 2003). In northern Arizona, fuel reduction resulted in reduced use of day-beds by mule deer for 3 years posttreatment (Germaine and others 2004). Treatments occurring on the wintering grounds of ungulates will likely be more beneficial, as winter forage is usually more limiting (Hobbs and Spowart 1984).

For centuries, Native Americans and land managers have used prescribed fire to improve habitat for ungulates, and it is generally agreed that prescribed fire improves the quality of browse vegetation (Bentz and Woodard 1988; Easterly and Jenkins 1991; Riggs and others 1996). In an aspen stand in Idaho, a prescribed fire greatly improved the amount and nutritional quality of forage for elk within one to two years after prescribed fire (Canon and others 1987). This finding is consistent with deer and elk responses to recovering vegetation after wildfire. For example, one year after a wildfire in Idaho, mule deer (Odocoileus hemionus) preferred the burned Douglas-fir/ninebark and burned ponderosa pine/bluebunch wheatgrass habitat types compared to unburned areas (Keay and Peek 1980). Although Keay and Peek (1980) found that white-tailed deer (Odocoileus virginianus) preferred unburned forests because of their preference for dense cover, white-tailed deer in a ponderosa pine forest in the Black Hills of South Dakota selected recently burned winter range (DePerno and others 2002), and this preference for burned habitats has been reported in other forest types as well (Main and Richardson 2002). White-tailed deer may be more likely to use treated stands if patches of dense cover are retained.

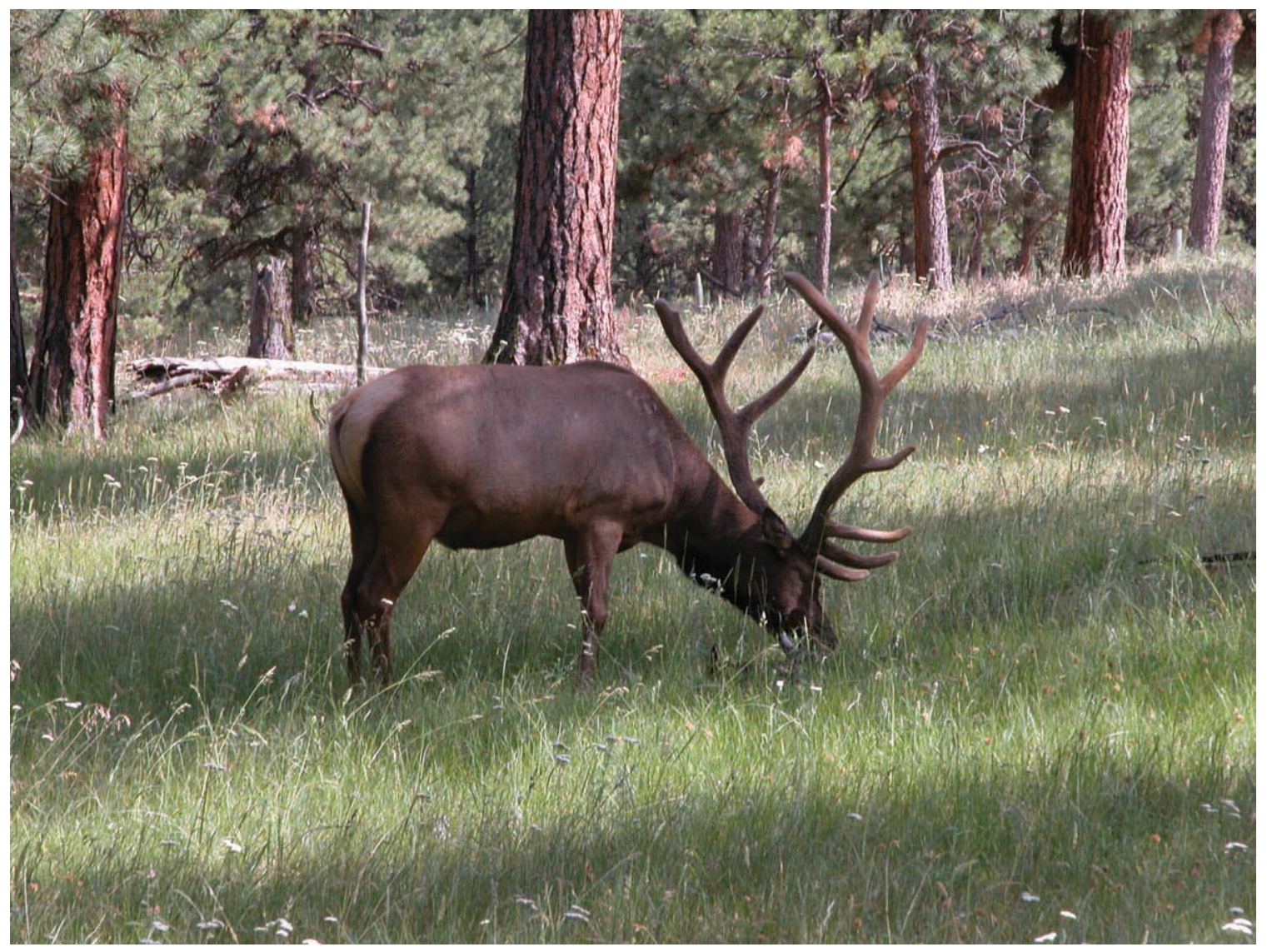

Figure 5-Fuel reductions usually increase the amount of forage for ungulates. Photo by Frank Vanni. 


\section{Small Mammals}

Cover and food resources are both essential to small mammal populations. Shrubs, down wood, and snags provide important cover from predators and thus the loss of these habitat elements may have negative consequences for some small mammal species (Chambers 2002). However, other species prefer open habitat conditions and may benefit from the food resources provided by early and mid-seral fruitproducing shrubs and the plentiful grasses and forbs that may establish after fuel reduction. Fisher and Wilkinson (2005) presented an extensive review of the effects of disturbance on mammals in boreal forests. They reported that small mammals recolonize disturbed areas soon after disturbance, although diversity and species dominance differ as succession progresses. Generalist species are typically dominant in the early successional stages, while specialist species are dominant in the later successional stages. When a decline in abundance of a particular species does occur, it is typically owing to a reduction in moisture and thermal cover, which can be a result of changes in coarse woody debris and in the herb and shrub layers (Fisher and Wilkinson 2005). A study in British Columbia reported that fuel reduction in young lodgepole pine forests increased the richness and diversity of small mammals, probably as a result of increased habitat heterogeneity (Sullivan and others 2001).

Small mammal species vary in their habitat preferences and thus in their responses to different types of treatments. A study in north-central Idaho found that southern red-backed voles (Clethrionomys gapperi) were most abundant in more closed-canopy mesic sites, whereas North American deer mice (Peromyscus maniculatus) and yellow-pine chipmunks (Tamias amoenus) predominated in open canopy xeric sites
(Koehler and Hornocker 1977). Both chipmunks and deer mice will likely increase in numbers after thinning in Douglas-fir and ponderosa pine forests (Goodwin and Hungerford 1979; Medin and Booth 1989; Woolf 2003) (fig. 6). Conversely, red-backed voles have been shown to decline after stands are clearcut but appear to continue to use selectively cut stands, at least in moist forest types (Campbell and Clark 1980; Steventon and others 1998). In a lodgepole pine and mixed conifer forest in northeastern Oregon, a commercial thinning designed as a fuels reduction treatment resulted in an increase in chipmunks and a decrease in red-backed voles, red squirrels (Tamiasciurus hudsonicus), and snowshoe hares (Lepus americanus) one year after thinning (Bull and Blumton 1999) (fig. 7). Hares continued to use very small patch-cut stands (10-m-wide circular cuts interspersed in unthinned stands and comprising 30 to 40 percent of a stand), but avoided stands thinned to a 4.2-m spacing (Bull and others 2005b). Retaining unthinned patches of trees within stands may help maintain hare populations in fuel treatment areas until understory vegetation recovers (Ausband and Baty 2005; Shick 2003; Sullivan and Sullivan 1988).

Some species of small mammals prefer high canopy closure and thus may be adversely affected by thinning treatments. For example, the Abert squirrel (Sciurus aberti) in ponderosa pine forests in north-central Arizona selects areas with high overstory canopy (Dodd and others 2003). Thinning will likely have a drying effect on high-canopy, high-density stands of grand fir (Lillybridge and others 1995), potentially having a negative effect on northern flying squirrel (Glaucomys sabrinus) populations (Lehmkuhl and others 2006). Northern flying squirrel abundance in dry Douglas-fir-ponderosa pine-western larch forests in northeastern Oregon decreased one to two years after a thinning treatment (Bull and others

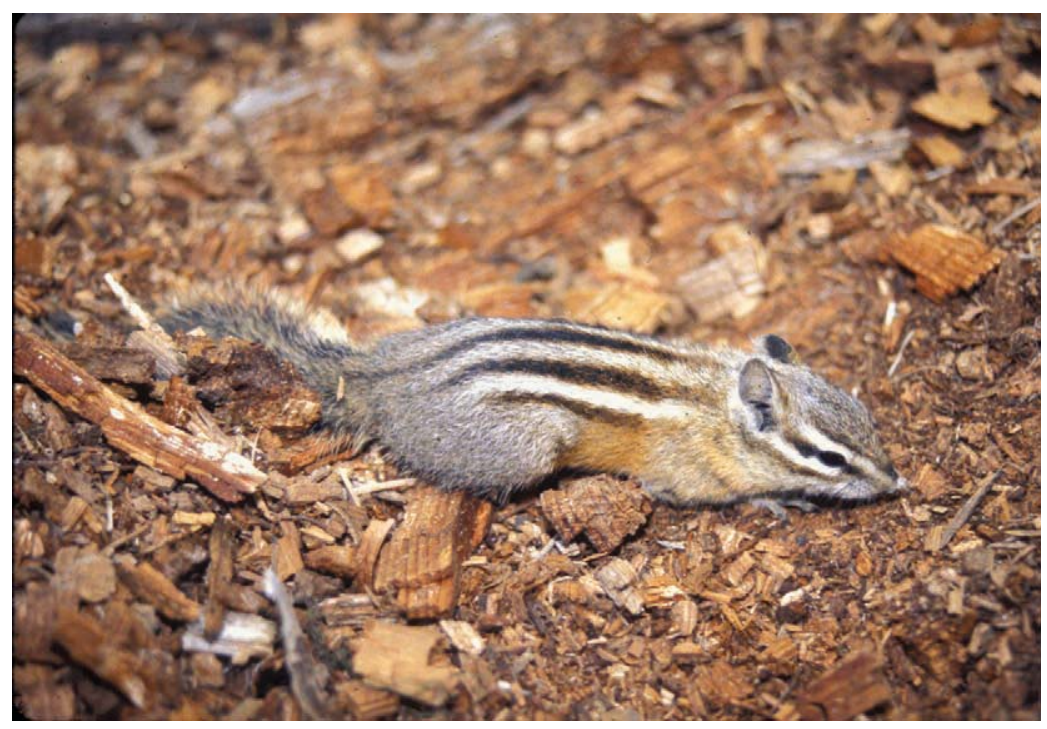

Figure 6-Chipmunks typically flourish after disturbance events like thinning and fire. Photo by Evelyn Bull. 


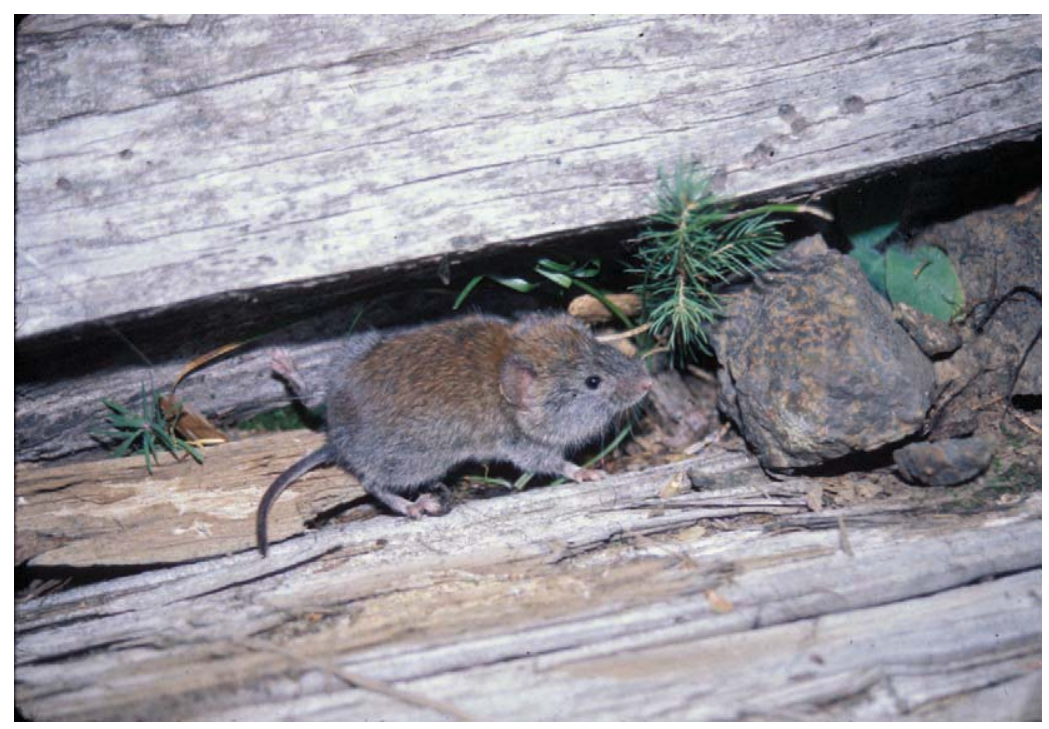

Figure 7-Red-backed voles may decrease after thinning and fire. Photo by Evelyn Bull.

2004), possibly as a result of habitat changes and decreases in truffles, the primary food of northern flying squirrels and other small mammals (Lehmkuhl and others 2004). Lehmkuhl and others (2006) concluded that thinned and burned stands would likely be poor bushy-tailed woodrat (Neotoma cinerea occidentalis) habitat in dry forests of eastern Washington due to their association with abundant large snags, mistletoe brooms and soft log cover. In dry mixed conifer

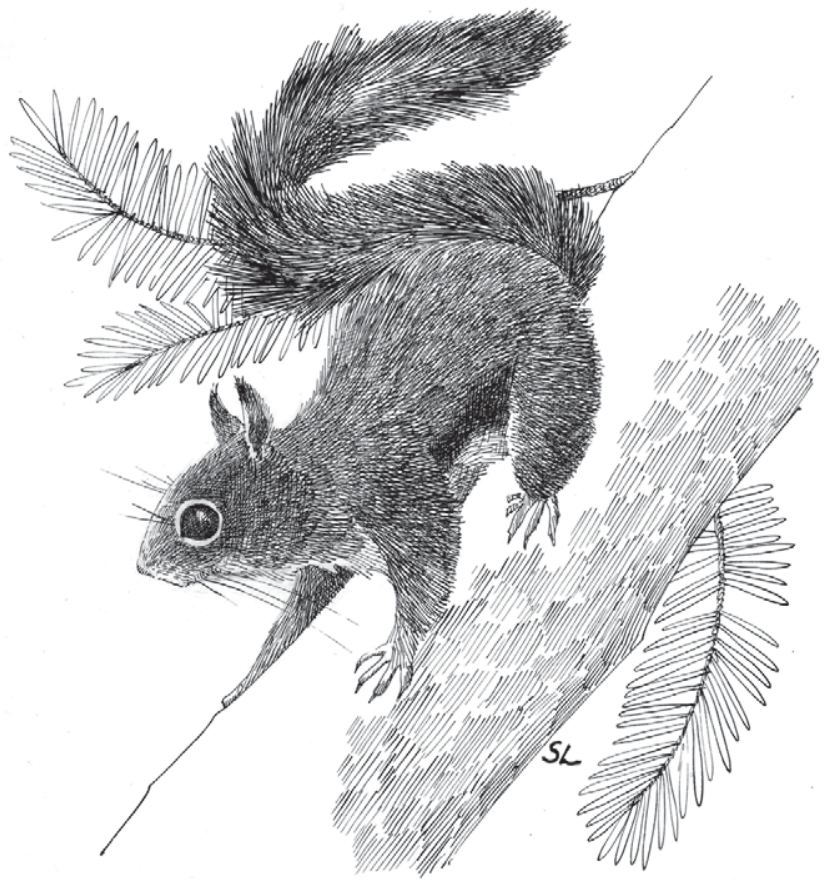

forests in the Sierra Nevada of California, truffle frequency, biomass, and species richness, and consequently consumption by lodgepole chipmunks (Neotamias speciosus), were lower in heavily thinned and thinned and prescribed burned plots compared with burn-only plots or unburned controls (Meyer and others 2005).

Relatively few studies have examined small mammal responses to prescribed fire, but inferences can be made from some wildland fire effects research. Short-term negative effects of fire have been observed for shrews (Sorex spp.) (Black and Hooven 1974), voles (Microtus spp.) (Dimock 1974), red-backed voles (Spildie and others, n.d.), rabbits (Lepus spp.), snowshoe hares (Keith and Surrendi 1971), red squirrels, and northern flying squirrels (Ream 1981). In contrast, deer mice (Dimock 1974, Spildie and others, n.d.), chipmunks, pocket gophers (Thomomys spp.), and ground squirrels (Spermophilus spp.) are favored by disturbances and are less affected by prescribed fires (Ream 1981). This response was demonstrated in ponderosa pine stands in South Dakota where deer mice increased the first year after a prescribed fire but decreased or remained the same the second year (Bock and Bock 1983). Deer mice, voles, and chipmunks also increased in spruce, lodgepole pine, and subalpine fir forests in British Columbia after clearcutting followed by prescribed fire (Sullivan and others 2001). All mammals, except the yellow-pine chipmunk, declined in stands of subalpine fir after prescribed fire in Washington (Hanson 1978). Studies from other regions and forest types show similar patterns of species-level differences in response to fire (Ahlgren 1966; Ford and others 1999; Kirkland and others 1996; Masters and others 1998). 


\section{Bats}

Bats are found in stands with appropriate roosting habitat (tall, large-diameter trees and snags) and abundant prey resources (flying insects). Little information is available on the direct effects of fuel reduction on bats overall, although some inferences can be made based on the known habitats used by bats. Long-legged myotis (Myotis volans), silver-haired bats (Lasionycteris noctivagans), and several other bat species roost under the bark of tall, large-diameter trees or in cavities of large snags (Betts 1998; Ormsbee and McComb 1998; Rabe and others 1998; Vonhof and Barclay 1996). In South Dakota, silver-haired bats roosted primarily under loose bark, in tree crevices, and in woodpecker cavities in ponderosa pine snags averaging about $39 \mathrm{~cm}$ dbh (fig. 8) (Mattson and others 1996). These stands contained an average of 21 snags per hectare (Mattson and others 1996).

If large-diameter snags and trees are protected during fuel reduction, it is likely that thinning or prescribed fire may have minimal or even positive effects on bat populations depending on the starting conditions and management history of the site (Boyles and Aubrey 2006; Patriquin and Barclay 2003; Schmidt 2003). However, the loss of these habitat features may be detrimental to forest bat species (Chambers and others 2002). In the Oregon Coast Range, bat activity in Douglas-fir stands was highest in old-growth stands, lowest in unthinned stands of second growth (50 to 100 years old), and intermediate in second growth stands with thinning (Humes and others 1999). Old-growth stands of Douglas-fir-western hemlock, ponderosa pine-sugar pine, and true firs were also preferred by hoary (Lasiurus cinereus) and silver-haired bats compared to younger stands in other parts of Oregon (Perkins and Cross 1988). Bat activity was higher in old growth stands of Douglas-fir than in mature and young stands in the southern Washington Cascades and in the Oregon Coast Range (Thomas 1988). The preference for old growth may be a function of the high density of large-diameter snags used as roosts; the open space between trees, which allows bats to gain flight when leaving the roost; or other factors. It is not known if stands with fuel reductions will function in the same capacitythroughout the interior dry coniferous forests of the West.

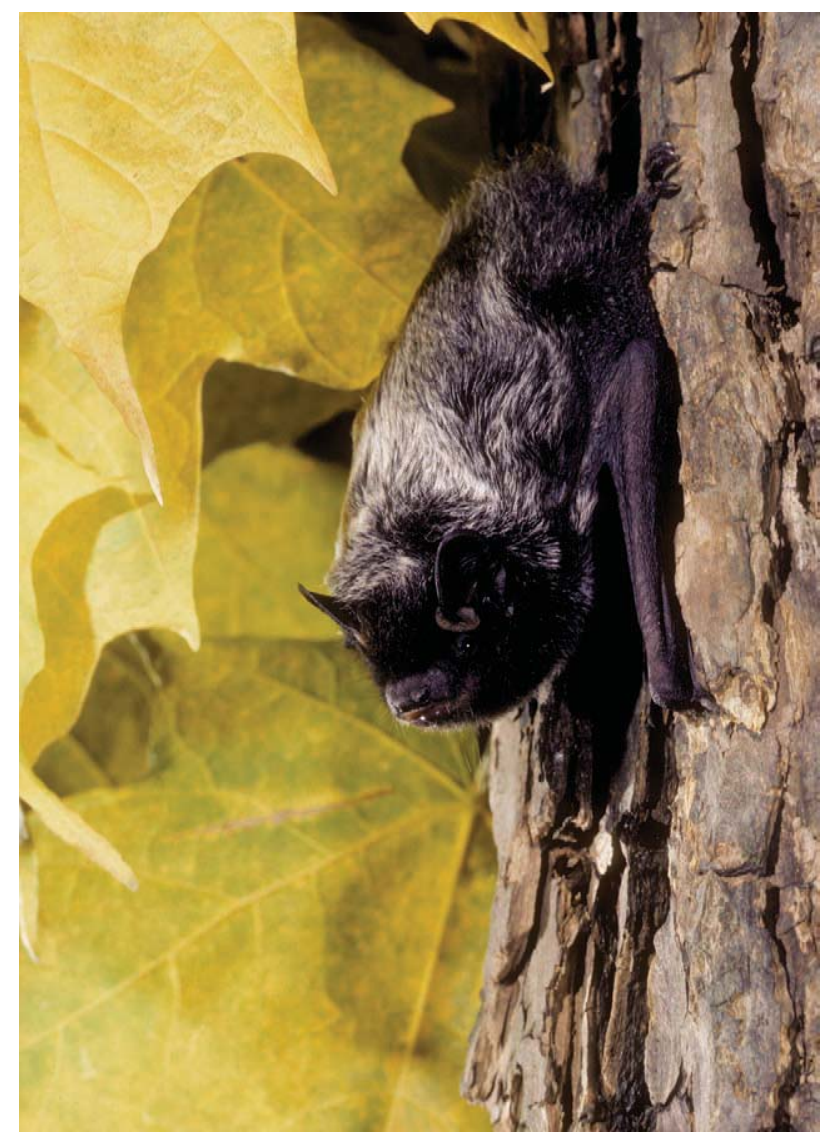

Figure 8-Silver-haired bats roost under loose bark and in cavities in large trees and snags, habitats that could increase or decrease depending on fuel reduction treatment. (C) Merlin Tuttle, Bat Conservation International Inc. 


\section{Species Implications-Birds}

\section{General}

Several factors influence the richness and diversity of bird species in a stand including the structure and composition of living and dead vegetation (Easton and Martin 2002; Steventon and others 1998; Taylor and Barmore 1980). In western dry coniferous forests, bird community composition depends on the heterogeneity of habitats available, proximity to water, fire history, and silvicultural legacy (Brawn and Balda 1988; Finch and others 1997; Hejl and others 2002). Like other wildlife, the species that are most likely to be affected by fuel reductions are those species whose nesting and foraging habitats are associated with the fuels being removed or created, and species that either prefer or avoid disturbed areas (fig. 9). Birds are often grouped based on foraging or nesting location or characteristics. Because of their great mobility as adults, population-level responses of birds are strongly influenced by their distribution and abundance in the surrounding landscape, although the existing conditions prior to treatment will also influence responses.

Patterns of bird responses to fire throughout North America have been recently summarized from published literature (Saab and Powell 2005), including chapters that synthesize information on dry coniferous forests (Bock and Block 2005; Saab and others 2005). The great majority of studies reported fire effects in terms of population change in relative abundance, during the breeding season, and within five years after fire. Bird responses were classified for 203 North American bird species as either positive, negative, inconclusive (that is, not enough data to determine the response), or mixed (that is, data suggest both a positive and negative response). Species were categorized by nest type (open vs. closed [cavity]), nest layer (canopy, shrub, ground or near ground), and foraging guild. Although this type of summary is necessarily coarse resolution (for example, does not distinguish between fire severity or time since fire), it still offers valuable insights and a basis for hypotheses. Some patterns in short-term responses to fire were apparent: (1) aerial, ground, and bark insectivores clearly favored burned habitats, whereas foliage gleaners preferred unburned habitats; (2) species with closed nests responded more favorably to burned habitats than species with open-cup nests; and (3) those nesting in the ground and canopy layers generally favored burned habitats compared to shrub nesters.

The reported effects of fuel reduction on birds are not always consistent among studies or species. For example, some studies observe an increase in bird abundance shortly after fuel reduction whereas others report large decreases or no change at all (Huff and others 2005; Moreira and others 2003). Shortterm responses may differ from long-term responses (Hannon and Drapeau 2005); breeding bird response may differ from wintering bird response (Bock and Block 2005); and effects observed at the stand scale may differ from those at the landscape or regional scale (Kotliar and others 2002; Saab and others 2002). However, some general effects are fairly predictable. First, thinning or prescribed fires conducted during the nesting season are more likely to result in high mortality of nestlings, especially for species nesting on the ground and in shrubs and small trees (Smith 2000). If conducted prior to the nesting season, prescribed fires are likely to reduce nesting habitat for ground- and shrub-nesting species (Artman and others 2001). Shrubs and ground cover lost during treatment will likely recover within a few years.

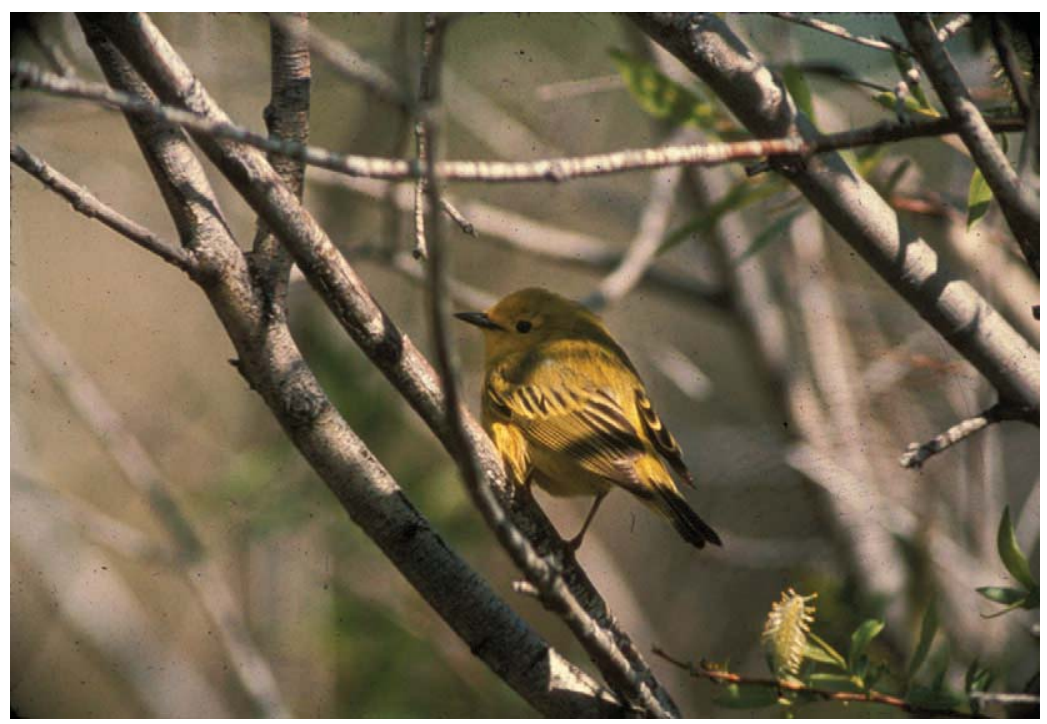

Figure 9-Yellow warblers will likely benefit from fuel reductions if tall shrubs increase with time. Photo by Don Bradshaw. 
Bird responses to prescribed fire are dependent on the species and other factors. Some bird species prefer early successional and open habitats, and these species are likely to increase in abundance after fuel reduction (DeGraaf and others 1991; Hagar and others 1996; Michael and Thornburgh 1971; Provencher and others 2002; Simon and others 2000; Wilson and others 1995). In ponderosa pine stands in South Dakota, the total number of breeding birds per transect was found to be higher in burned areas compared to controls only in the first summer after a fire (Bock and Bock 1983). In contrast, some birds may be less abundant after prescribed fire (Anderson and Crompton 2002; Gaines and others, in press). For example, foliage gleaners prefer unburned forests and often decrease in abundance with increasing burn severity (Kotliar and others 2002). Burning operations that remove large trees and snags will likely affect species nesting in tree canopies and cavities of snags or live tree boles (fig. 10). Recruitment of large snags for cavity nesters may take decades or longer, depending on existing stand conditions.
Prescribed fire can also alter bird foraging habitats and the primary components of bird diets, such as insect populations and fruit production of plants (Dickson 1981). Any fuel-reducing activity that removes a bird's preferred foraging habitat will likely result in adverse affects, at least in the first few years after treatment. For example, tree gleaners declined after thinning in an Idaho ponderosa pine-Douglas-fir forest (Medin and Booth 1989). A potential increase in food supply (seeds and insects) following fire might provide better foraging for these birds because there is greater access owing to the removal of grass layers. This increase in food supply influences mostly granivorous species and some omnivorous and carnivorous species that feed on the ground (Artman and others 2001). Burn edges can also be important for some birds by providing a heterogeneous mix of burned and unburned trees, possibly providing opportunistic foraging while maintaining cover from predators. Hence, the juxtaposition of live and dead trees may be important for some species such as the olive-sided flycatcher (Altman and Sallabanks 2000; Kotliar and others 2002).

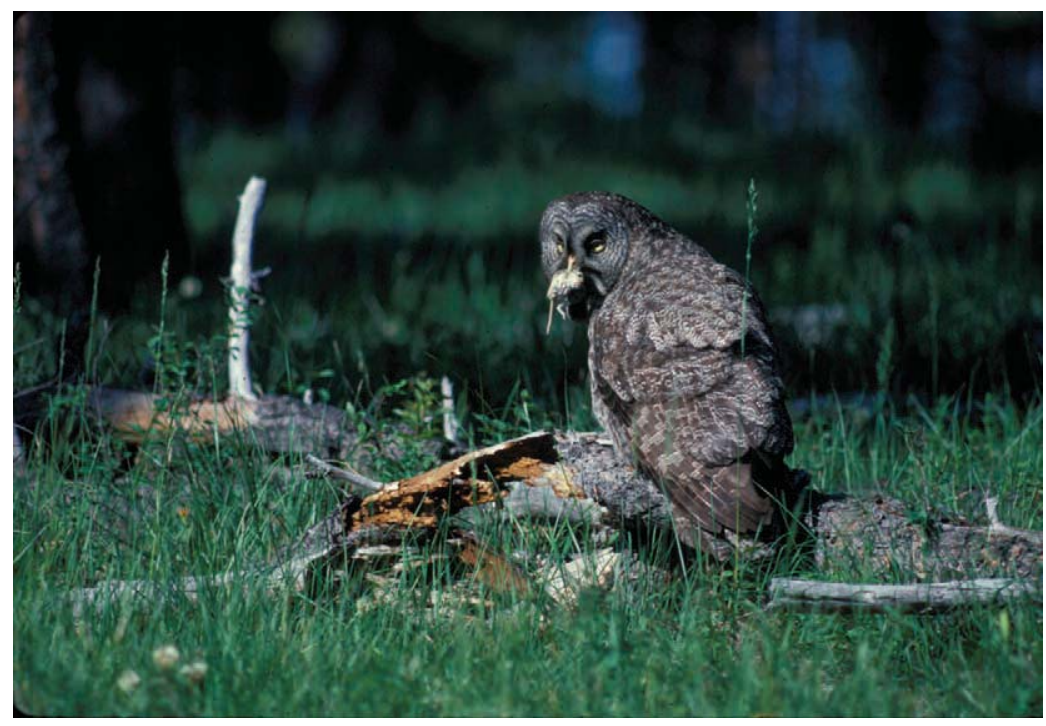

Figure 10-Great gray owls may benefit from the more open forest structure resulting from fuel reductions, but the loss of nest sites in large-diameter snags and mistletoe brooms would be detrimental. Photo by Evelyn Bull. 


\section{Raptors}

The more open understory created by fuel reduction may be advantageous to some species of hawks, owls, and eagles that prey on small mammals and birds in open forests and small clearings (fig. 10). Prey species that have less cover are more easily captured, and some prey species prefer open forests (for example, deer mice). However, some raptor species and some small mammal and avian prey prefer closed canopy forests and thus may avoid stands that have been treated to reduce fuels. The removal of trees with dwarf mistletoe brooms during thinning treatments will likely be detrimental to wildlife species that nest in mistletoe brooms including the great gray owl (Strix nebulosa), long-eared owl (Asio otus), great horned owl (Bubo viginianus), northern spotted owl (Strix occidentalis), northern goshawk (Accipiter gentilis), Cooper's hawk (Accipiter cooperii), and red-tailed hawk (Buteo jamaicensis) (Bull and others 1997).

Northern goshawks prefer closed canopy forests of largediameter trees with relatively open understories (Reich and others 2004). Management recommendations for sustaining habitat for the northern goshawk and their prey include prescribed fire, thinning from below to achieve nonuniform spacing of trees larger than $46 \mathrm{~cm}$ dbh, not to exceed 30 to 50 percent canopy opening, and various slash treatments (Reynolds and others 1992; Squires and Reynolds 1997). A single moderate-level thinning in even-aged 30- to 35-year-old stands is recommended in moist forests on the Olympic Peninsula to achieve high crown base heights $(>25 \mathrm{~m})$ and low shrub cover

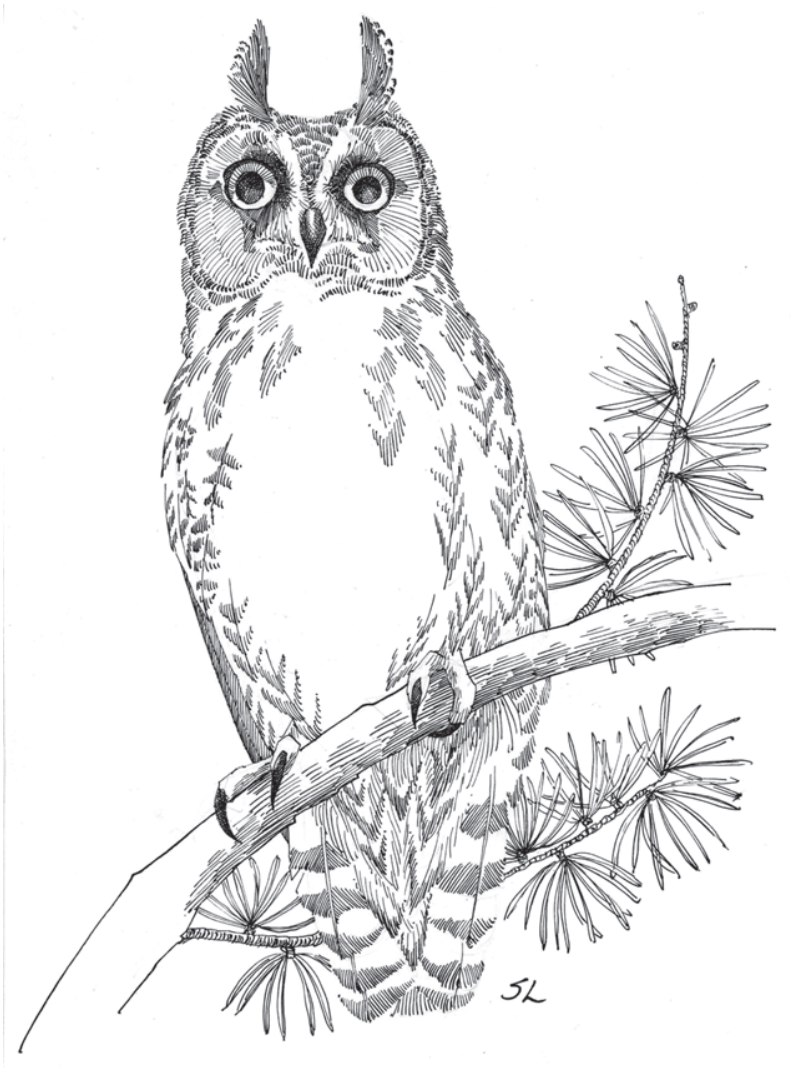

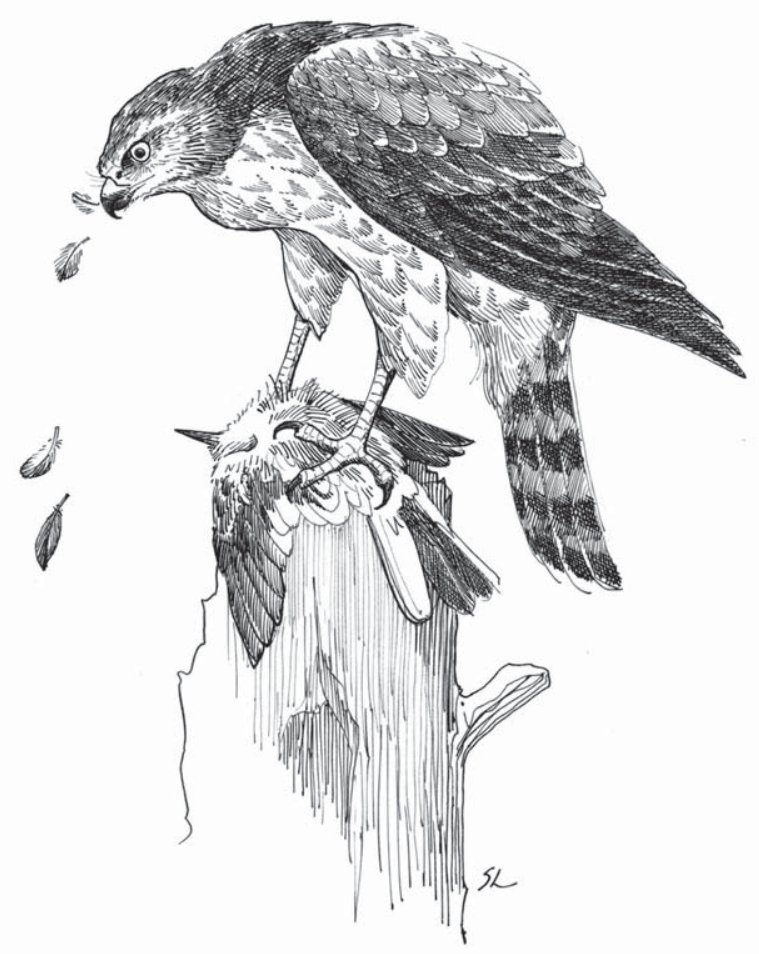

(<20 percent) to improve habitat for northern goshawks (Finn and others 2002). In the Southwest, Beier and Maschinski (2003) recommend no restoration activities in the nest area (a 73-ha area around each nest), except for possibly thinning from below to reduce the risk of stand-replacing fire.

Both Mexican spotted owls (Strix occidentalis lucida) and northern spotted owls (Strix occcidentalis caurina) are listed under the federal Endangered Species Act and are found in dry forest environments. Management objectives for both species are conservatory with little active management in defined areas. By reducing the risk that stand-replacement fire will sweep into these defined areas, restoration treatments outside of these areas should benefit spotted owls over the long-term (Beier and Maschinski 2003). In Arizona and New Mexico ponderosa pine and mixed conifer forests, relatively light fires, including most prescribed fires, had no clear short-term effect on Mexican spotted owl presence or reproduction (Jennes 2000). Variable-density thinning may hold promise for acceleration of the development of northern spotted owl habitat and dense prey populations (Carey 2001, 2003; Carey and others 1999a, b; Carey and Wilson 2001; Muir and others 2002) especially when appropriate attention is paid to decadence (snags, cavity trees, and coarse woody debris) (Bunnell and others 1999; Carey 2002; Carey and others 1999a, b) though these results may be best suited in mixed conifer stands with mixed-severity fire regimes rather than the drier pine, low-intensity fire regimes (Lehmkuhl and others 2006). Although vegetation manipulation to reduce wildfire hazard may create less than optimum habitat for the northern spotted owl, this should be weighed against the hazard for stand replacement fires and the complete loss of habitat over large areas (Everett and others 1997). 


\section{Cavity-Nesting Birds}

If fuel treatments involve removing or eliminating snags, then a net loss of nesting habitat for primary and secondary cavity-nesting birds might be expected for many years (Scott and Oldemeyer 1983). Prescribed fire, depending on the intensity, will likely increase the number of small-diameter snags, but these snags are generally less suitable habitat for cavity-nesting birds. Primary cavity nesters excavate nest cavities in large trees and large snags. The value of and preference for large-diameter snags for nesting has been well documented for the pileated woodpecker (Dryocopus pileatus), hairy woodpecker (Picoides villosus), northern flicker (Colaptes auratus), and Williamson's sapsucker (Sphyrapicus thyroideus) in dry forests in northeastern Oregon (Bull 1986), woodpeckers in ponderosa pine forests in central Oregon (Bate 1995; Dixon 1995), pileated woodpeckers in Montana (McClelland and others 1979), and cavity nesters in ponderosa pine forests after wildfires in southwestern Idaho (Saab and Dudley 1998; Saab and others 2002) and northern Arizona (Chambers and Mast 2005). Additionally, previously excavated cavities provide nesting, roosting, and shelter habitat for secondary cavity-nesting birds and some mammals (Bull and others 1997; Hay and Guntert 1983; Saab and others 2004).

The majority of research studies report that thinning or thinning and burning fuel treatments result in a decrease in populations of cavity nesters owing to loss of dead trees used for nesting and roosting. Preliminary results of a study in southeastern British Columbia indicate that thinning treatments in dry Douglas-fir and ponderosa pine forests resulted in a decline in snag densities, cavity-nesting bird densities, and species richness of cavity nesters in the first two breeding seasons following thinning (Machmer 2002). In northeastern Oregon, 65 percent of pileated woodpecker foraging occurs in down wood and snags (Bull 1987) (fig. 11). Pileated woodpecker foraging was highest in untreated stands of ponderosa pine-Douglas-fir-grand fir, lowest in stands that had been thinned and burned one to three years previously, and intermediate in thinned stands (Bull and others 2005a). The prescribed fire in this study also eliminated more than 10 pileated woodpecker nest and roost trees (past and current) in one 18-ha stand averaging more than $80 \mathrm{~cm} \mathrm{dbh}$. However, other factors may be influencing cavity-nesting bird responses to fire, some of which may be beneficial depending on burn severity. For example, in stand-replacement fires in ponderosa pine forests in Idaho, nest success of six cavity-nesting birds (2-5 years postfire) was generally higher than nest success reported in the literature from studies conducted in unburned forests (Saab and others 2005).

Prescribed fire results in variable snag creation and loss across a stand. Finch and others (1997) reviewed studies that evaluated the effects of prescribed fire on snags and down wood in southwestern ponderosa pine forests and found that snag loss was greatest in the large size classes and in the decay classes (those with decayed heartwood) that contained nest cavities. Snag loss typically ranged from 20 to 48 percent and

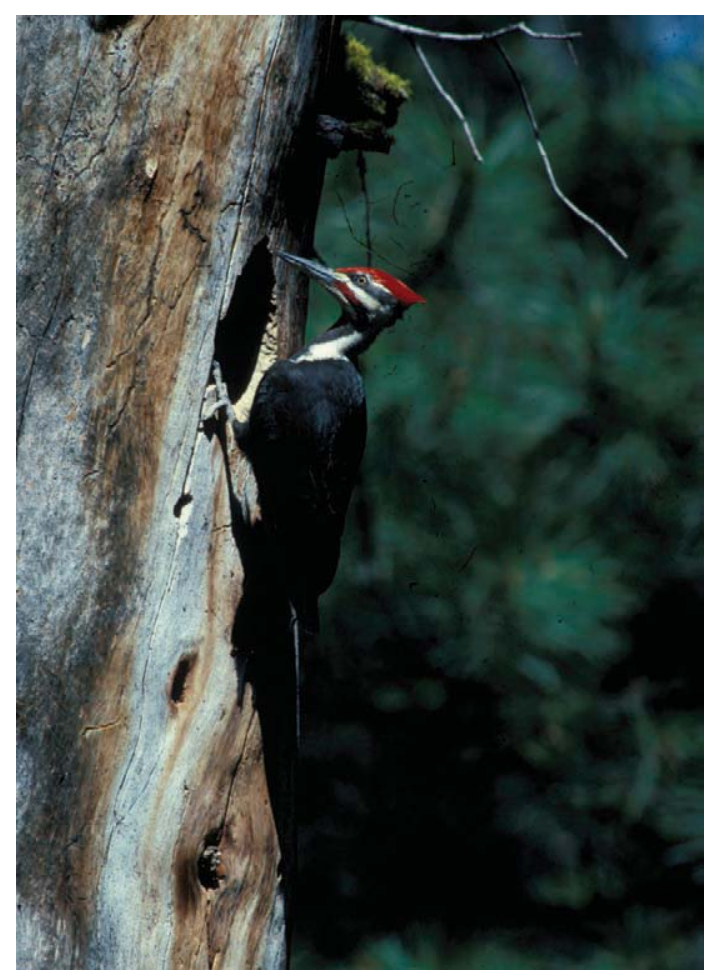

Figure 11-The loss of down wood and snags in fuel reductions would be detrimental to pileated woodpeckers. Photo by Evelyn Bull.

loss of down wood (logs) from 42 to 74 percent depending on the burn intensity and dead wood characteristics (in other words, decay state and moisture) and size classes (reviewed in Finch and others 1997; Randall-Parker and Miller 2002). A net 45-percent decrease in snags followed a prescribed fire in a southwestern pine-oak forest dominated by ponderosa pine (Horton and Mannan 1988). Proportional snag loss in this study was greatest in the size $(>50 \mathrm{~cm} \mathrm{dbh})$ and decay classes that contained the most nest cavities.

Some studies also report a short-term benefit in creating snags used for foraging due to an increase in bark beetles caused by the treatment. Horton and Mannan (1988) found there was a 20 -fold increase in new snags $<15 \mathrm{~cm}$ dbh; 64 percent of these newly created snags were used by woodpeckers for foraging within one year of being created. If prescribed fires are conducted over large areas, there may be a short-term benefit to woodpeckers in the Picoides genus which forage on recently burned trees (Rudolph and others 2002) (fig. 12). Fires that do not consume large snags may improve ponderosa pine habitat for breeding Lewis's woodpeckers (Melanerpes lewis) due to a decrease in canopy cover which is preferred habitat for this species (Saab and Vierling 2001). Fuel reductions may be beneficial for white-headed woodpeckers (Picoides albolarvatus) because this species is attracted to open areas in older mature forests with low shrub cover in ponderosa pine stands in central Oregon (Frenzel 2004); the open areas may be created by silvicultural treatments, although nesting success was depressed at these sites. 


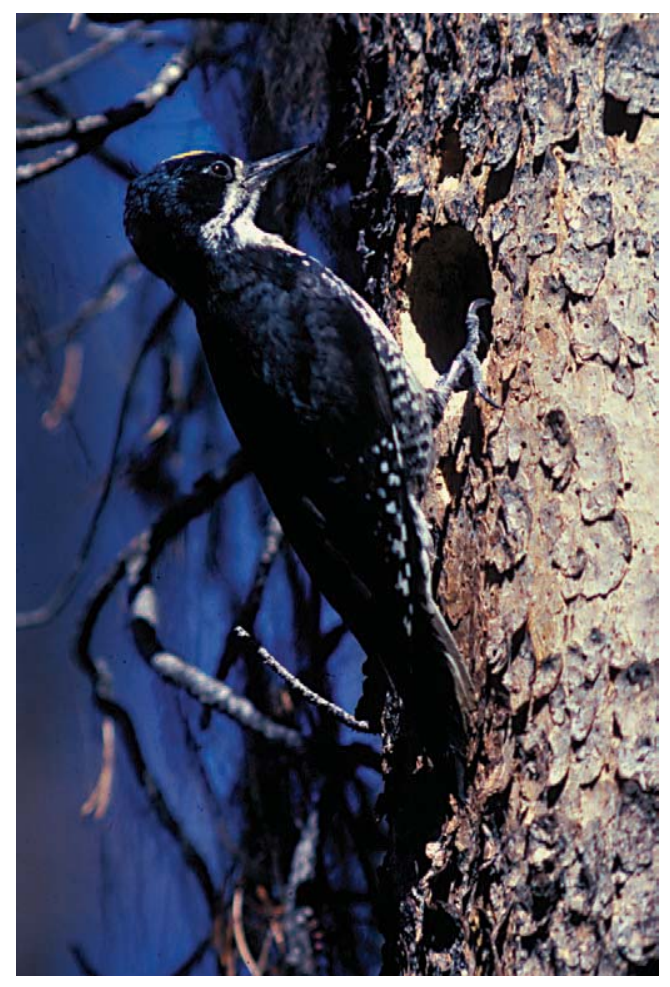

Figure 12-Black-backed woodpeckers move into burned areas to forage on bark and woodboring beetles that invade the scorched trees. Photo by Evelyn Bull.
Maintaining a minimum number of snags per hectare in a ponderosa pine or Douglas-fir stand may be insufficient given the ephemeral nature of snags (in other words, continually changing in height, decay state, and presence of sapwood decay organisms) (Parks and others 1999; Zack and others 2002). Wildfire research in dry forests in Idaho suggests that cavity excavation increases with time since fire, but that most cavities are only used once by seven of the eight woodpecker species that were considered (Saab and others 2004); thus a continual supply of snags is needed to maintain new nesting sites over time.

The response of secondary cavity nesters to fuel reduction in ponderosa pine and Douglas-fir forests will likely follow a pattern similar to primary cavity nesters, including some positive, negative, and neutral responses (Medin and Booth 1989). Clutch size and number of nestlings of the western bluebird (Sialia mexicana), a secondary cavity nester, did not differ between control stands and stands thinned and burned in ponderosa pine forests in Arizona (Germaine and Germaine 2002). Bluebirds had a higher probability of successfully fledging young in treated stands but with greater risk of parasitic infestations (Germaine and Germaine 2002). After prescribed fire in ponderosa pine forests in southeastern Arizona, northern flickers and violet-green swallows (Tachycineta thalassina) decreased in abundance and mountain chickadees (Parus gambeli) increased in abundance when compared to numbers in adjacent unburned control stands over the same periods (Horton and Mannan 1988).

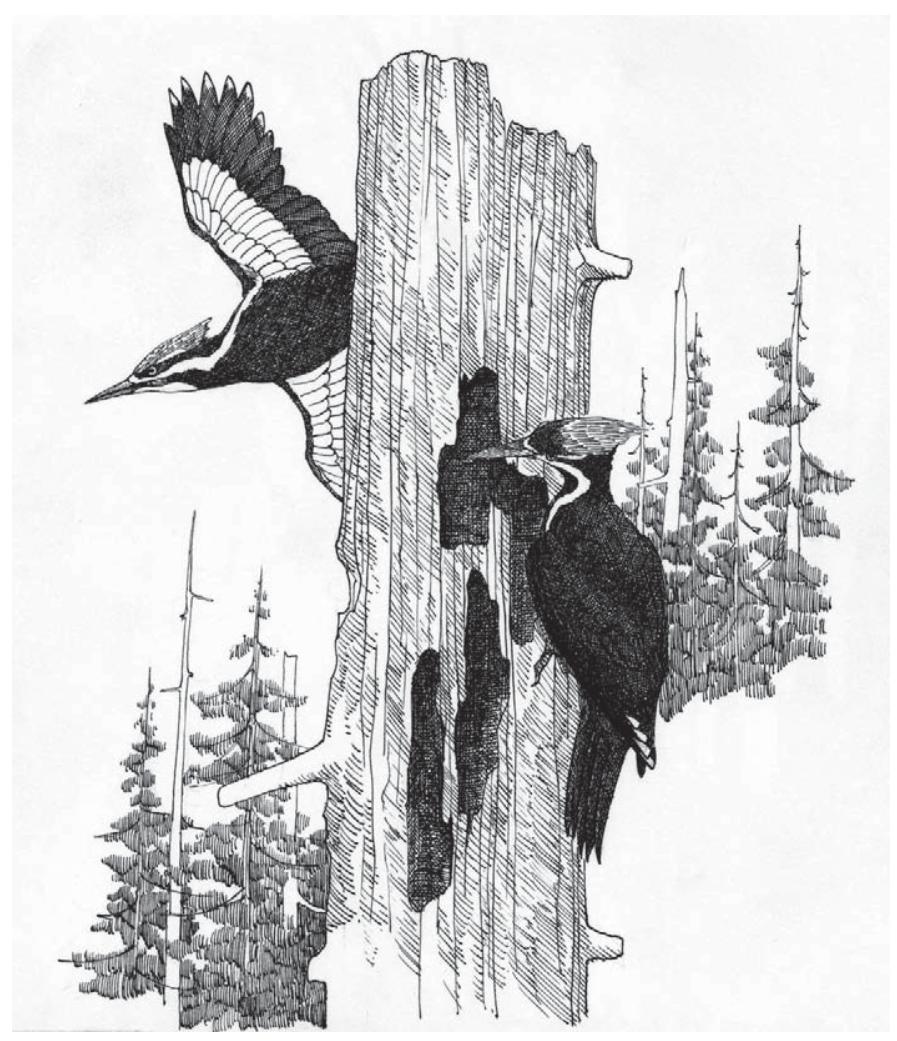




\section{Species Implications-Reptiles}

In general, reptile diversity is lower in forested habitats compared to desert, grassland, and chaparral (Pough and others 2004). Few lizard and snake species occupy closedcanopy coniferous forests in the Western United States except for possibly the rubber boa (Charina bottae) (fig. 13). Other species inhabit specific patches within forests, such as wetlands, meadows, and rock outcroppings that provide shelter, microclimates, and prey (Heatwole 1977; Lillywhite 1977). These species will primarily include the western fence lizard (Sceloperus occidentalis), eastern fence lizard, (Sceloporus undulatus), sagebrush lizard (Sceloporus graciosus), ornate tree lizard (Urosaurus ornatus), western skink (Eumeces skiltonianus), northern alligator lizard (Elgaria coerulea), garter snakes (Thamnophis spp.), mountain king snake (Lampropeltis zonata), racer (Coluber constrictor), gopher snake (Pituophis catenifer), and western rattlesnake (Crotalus viridis).

Very little is known about the effects of thinning on reptiles, and we found no studies specific to the dry coniferous forests. In general, species responses to fuel reduction depend upon habitat preferences and how those habitats are altered by the treatment (Russell and others 1999). Although a few species prefer forest floor cover, others will likely benefit from the reduction in shrubs, ground vegetation, and litter cover and depth (Germaine and Germaine 2002; Knox and others 2001; Mushinsky 1985; Singh and others 2002).

Prescribed fire does not appear to adversely affect most reptiles, and general patterns suggest that some species prefer postfire environments (Brisson and others 2003; Litt and others 2001; Moseley and others 2003; Russell and others 1999; Singh and others 2002). In central Arizona, lizard species richness was greater in burned ponderosa pine forests compared to adjacent unburned areas for three years after catastrophic wildfire (Cunningham and others 2002). Total lizard abundance in burned ponderosa pine forests was four to nine times that of unburned forests, but it varied year to year and was strongly influenced by eastern fence lizard captures, which represented 78 percent of all lizard captures in forested plots. The high numbers of lizards captured in burned areas have generally been attributed to increases in habitat quality for species that prefer open habitat, prefer large woody debris, and benefit from postfire food resources such as insects (Lillywhite 1977; Lillywhite and North 1974). Short-term loss of vegetation cover does not appear to limit lizard habitat use (Cunningham and others 2002). Many lizard species prefer snags and down wood over live trees (James and M'Closkey 2003) and use charred branches for perching (Lillywhite and North 1974; Lillywhite and others 1977). Fuel reduction treatments that leave these habitat elements on site may improve habitat for species. Other studies (from outside our focal area) suggest that immediate population declines are occasionally associated with prescribed fire (Patterson 1984; Setser and Cavitt 2003; Singh and others 2002; Trainor and Woinarski 1994), but these are usually short-term effects. Maintaining unburned areas close to burned areas may help facilitate snake and lizard recolonization or use of burned areas (Brisson and others 2003; Setser and Cavitt 2003).

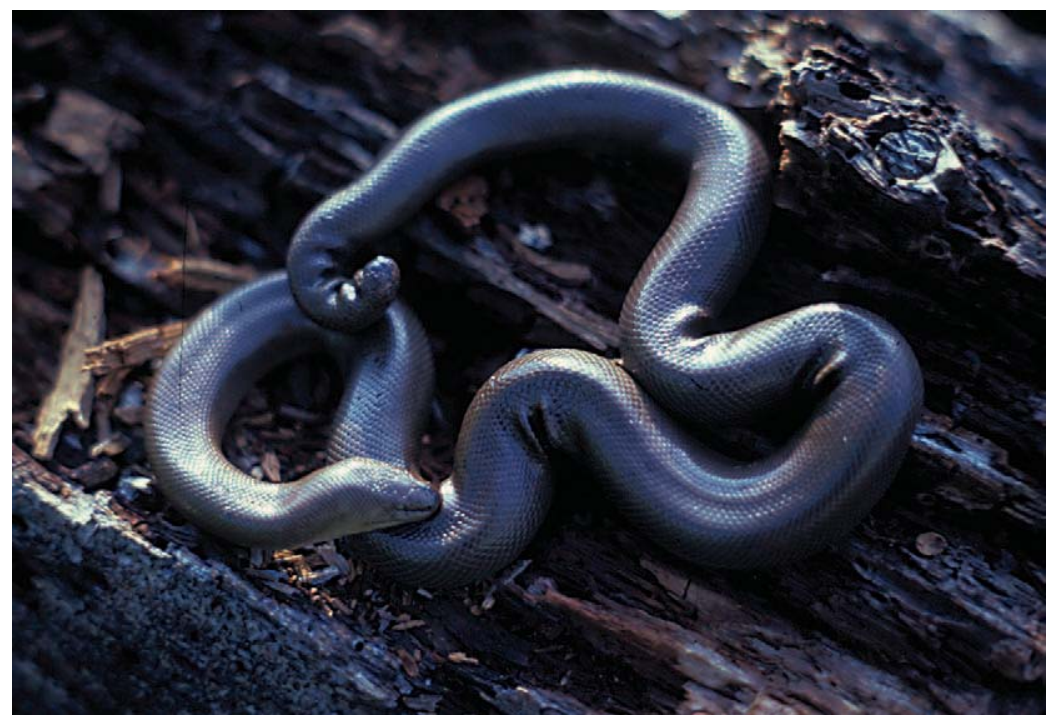

Figure 13-Rubber boas are a species that may be detrimentally affected by fuel reductions owing to the loss of down logs that they use for cover and foraging. Photo by Evelyn Bull. 


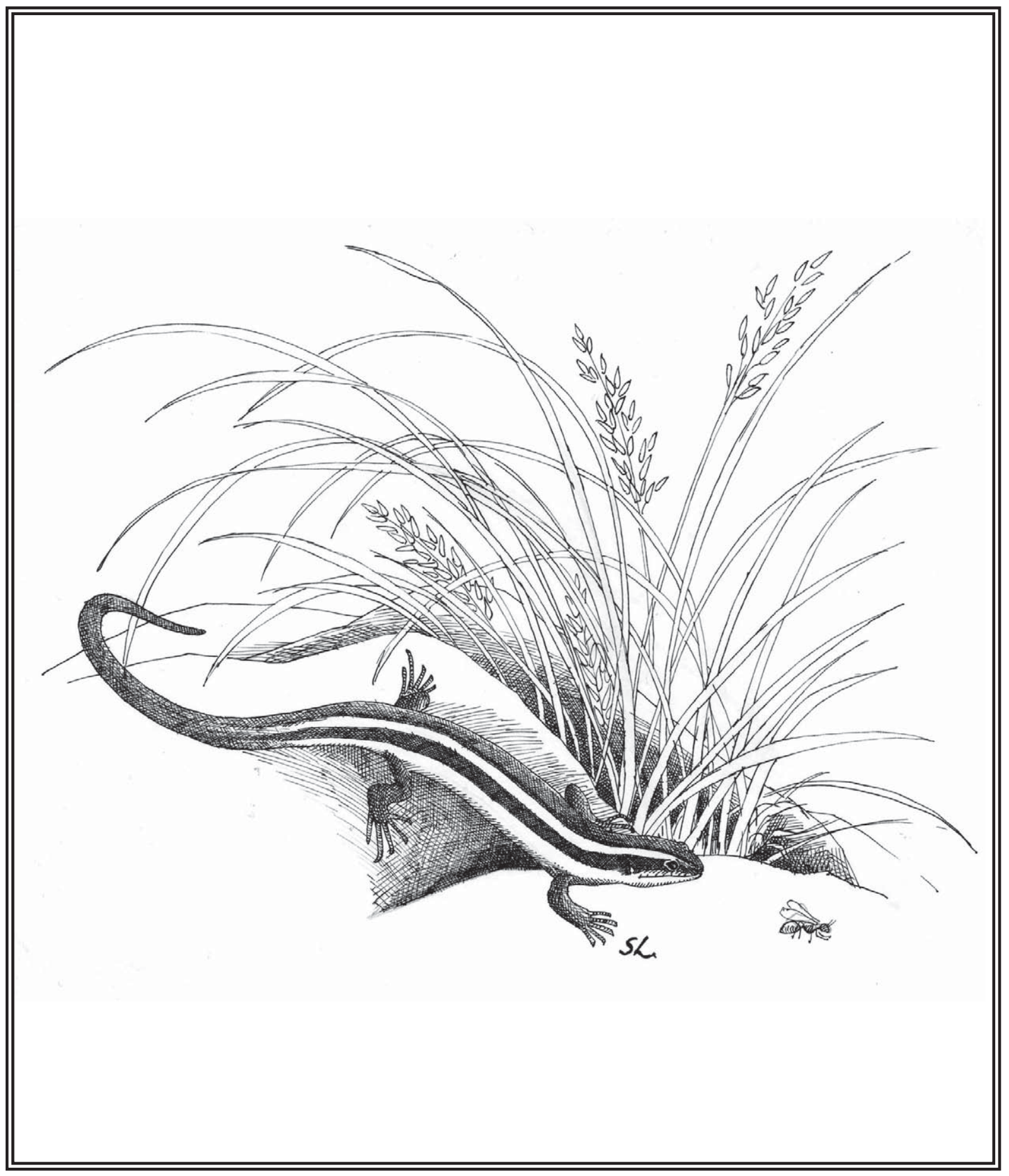




\section{Species Implications-Amphibians}

A few amphibians are strictly aquatic, but most use upland habitats at various times during the year, and a few species are strictly terrestrial. Upland habitat use by forest amphibians largely depends on the availability of moist duff and litter and rotting down wood. Unlike reptiles, amphibians' response to reducing canopy cover will likely be less favorable because of the warmer and drier conditions created in the understory vegetation, down wood, litter, and soil (Heatwole 1962; McGraw 1997; Meyer and others 2001; Pough and others 1987). Most terrestrial salamanders require moist soils or decomposing wood to maintain water balance, and dry conditions usually result in suppressed populations (Bury and Corn 1988; deMaynadier and Hunter 1995). Anurans (frogs and toads) may be less affected by changes in environmental conditions associated with fuel reduction because of their tendency to travel at night and during rain events, their greater vagility than salamanders, and their close association with wetlands (Constible and others 2001; Pilliod and others 2003). Still, species that frequently occupy terrestrial habitats such as many salamanders, boreal toads (fig. 14), and tree frogs may be killed during fuel treatments or find posttreatment conditions unsuitable (Pilliod and others 2003).

We know of only one study that has quantified the effect of thinning on amphibians in dry coniferous forests. In a lodgepole pine forest in western Montana, 70 percent fewer long-toed salamanders (Ambystoma macrodactylum) were captured in selectively harvested stands compared to unharvested stands (Naughton and others 2000). However, the authors also reported no differences in understory vegetation, woody debris, or litter between harvested and unharvested plots and thus the effects of these treatments are contrary to most fuel reduction treatments. Still, the authors suggest that differences in salamander numbers were attributed to the reduction in overstory canopy and subsequent increases in mean ambient temperatures (Naughton and others 2000). The importance of overstory canopy has been demonstrated for other amphibian species in the central Oregon Coast Range (Martin and McComb 2003).

The effects of prescribed fire on amphibians is highly variable and strongly influenced by the location of fires in proximity to breeding habitats (generally wetlands), season of fire, and amphibian species (see reviews by Bury 2004; Bury and others 2002; deMaynadier and Hunter 1995; Pilliod and others 2003; Russell and others 1999). To date, few studies have been published on the effects of prescribed fire on amphibian populations in dry coniferous forests of the West (see table 1 in Pilliod and others 2003). Comparing amphibian populations before and after logging and burning of activity fuels in western Oregon, Cole and others (1997) found that capture rates of terrestrial Ensatina (Ensatina eschscholtzii) and giant salamander (Dicamptodon tenebrosus) decreased in treatment stands relative to untreated controls. In contrast, Vreeland and Tietje (2002) found similar abundances of slender salamanders (Batrachoseps attenuatus) in California oak woodlands before and after prescribed fire.

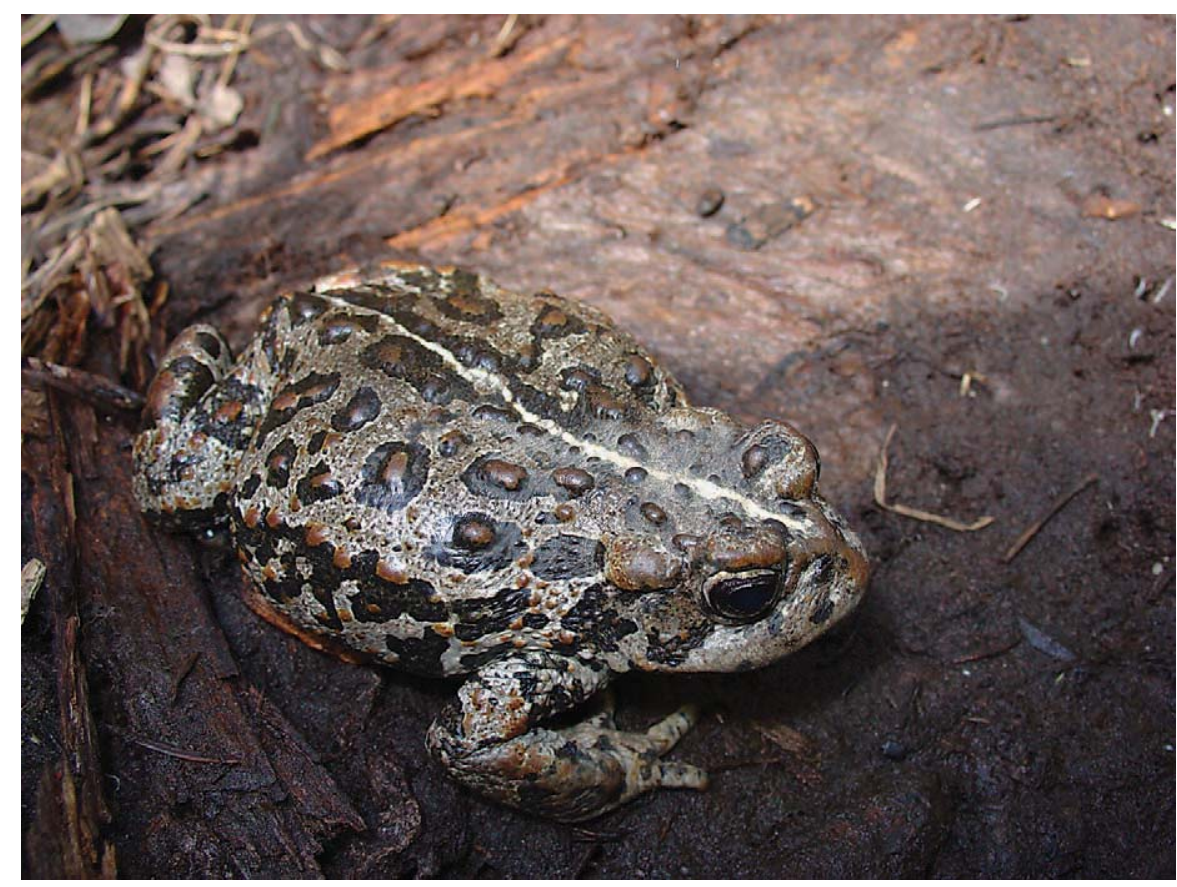

Figure 14-Boreal toads readily occupy burned habitats, foraging on ants and ground beetles and finding shelter under logs and rocks and in rodent burrows. Photo by David Pilliod. 
There is concern that fuel treatments may contribute fine sediment to streams because of increased surface runoff (Elliott and others 1999; Robichaud 2000; Robichaud and Waldrop 1994). Sedimentation causes reduced survivorship of eggs and tadpoles of some stream-breeding amphibians that lay their eggs and rear tadpoles under rocks or within interstitial spaces in the substratum (Corn and Bury 1989; Gamradt and Kats 1997; Gillespie 2002).

Some amphibians may benefit from fuel treatments. For example, boreal toads (Bufo boreas) appear to be attracted to recently disturbed areas and may benefit from fuel reduction projects (fig. 14). Toads colonized and bred in dozens of shallow ponds in burned lodgepole pine forests in Glacier National Park but not in adjacent unburned areas (Corn and Hossack, n.d.). Although the environmental factors attracting the toads to the ponds in the burned forests are unclear, another study found toads in greater abundances in burned forests (Kirkland and others 1996). In northeastern Oregon, diet samples from boreal toads in burned subalpine fir and lodgepole pine forests contained higher numbers of prey items (82 percent ants) than samples obtained from toads in unburned forests (Bull, in press). In the mid-Atlantic and southeastern United States, substantial research has been conducted on the effects of prescribed fire in fire-prone ecosystems and found that fire is important for maintaining habitats for several amphibians (Means and Campbell 1981; Means and others 2004; Mushinsky 1985). However, our understanding of how best to manage the fire-return interval in forests with thinning and prescribed fire needs more attention (Means and others 2004; Pilliod and others 2003; Semlitsch 2000; Schurbon and Fauth 2004). Although many species appear minimally affected by fuel treatments (Ford and others 1999; Kirkland and others 1996; Litt and others 2001), some amphibian populations may experience shortterm negative effects (McLeod and Gates 1998; Schurbon and Fauth 2003).

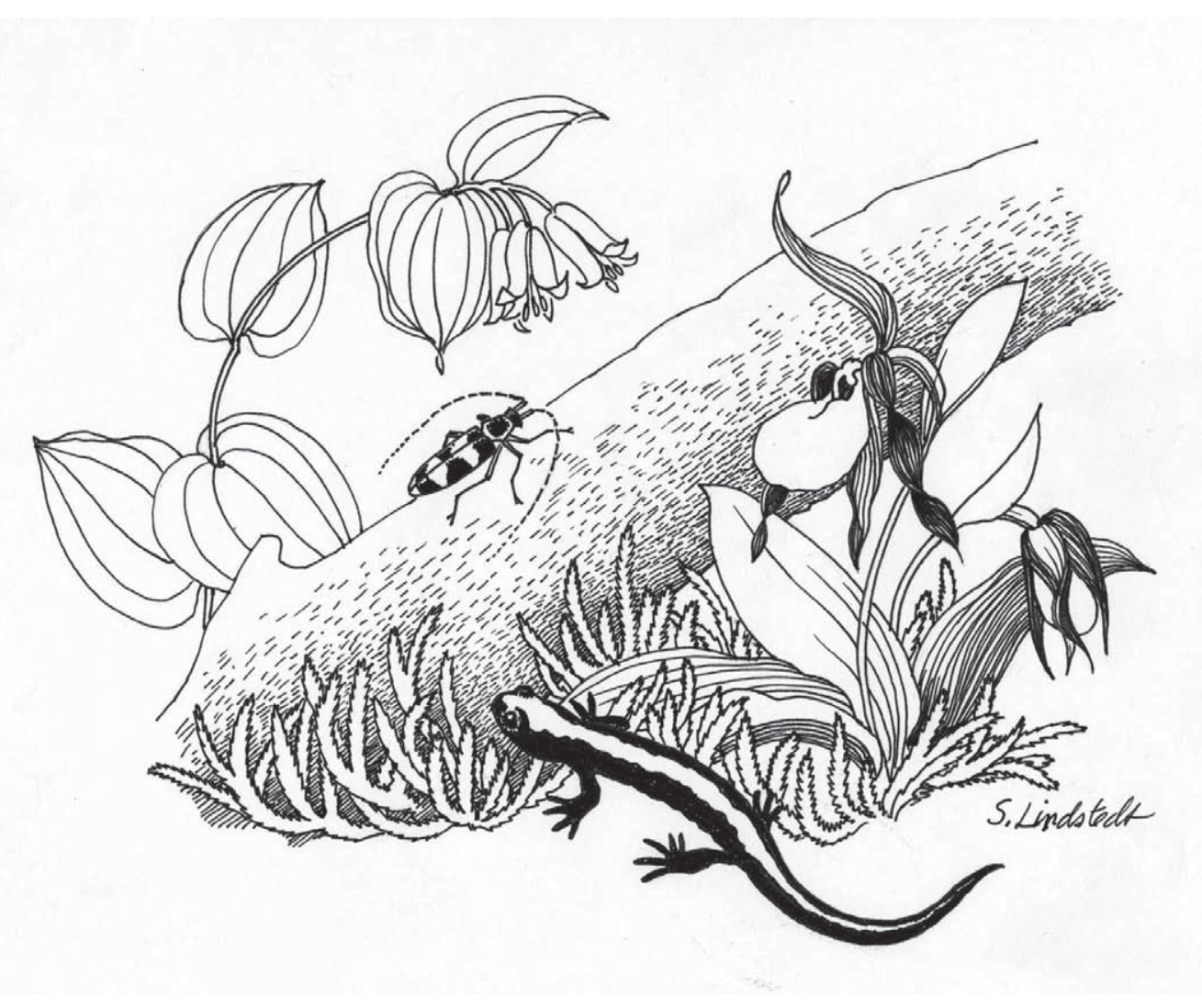




\section{Species Implications-Invertebrates}

\section{General}

The effects of fuel treatments on terrestrial invertebrates in western dry coniferous forests are likely to be as diverse as the group itself. The group includes the highly diverse arthropods (insects, spiders, mites, scorpions, centipedes, millipedes, isopods), annelids (segmented worms), and mollusks (snails and slugs). Invertebrates compose over half of the animal diversity across broad landscapes, including forested lands (Niwa and others 2001b). This number is even higher if undescribed species are included. For example, in the Columbia River basin, less than 20 percent of an estimated 24,290 species have been described (Niwa and others 2001b). Invertebrates occupy all forested habitats and have diverse functional roles including detritovores, predators, herbivores, and pollinators. Many invertebrates are specifically associated with shrubs, snags, litter, and duff, habitat elements targeted in fuel treatments.

Most invertebrates occupy distinctly different habitats during their life cycle. For example, some species live below ground as immatures and above ground as adults or feed on vegetation as immatures and then on flower nectar as adults. Because forest invertebrates are short lived and either have short dispersal ranges or are sedentary in one or more of their life stages, fuel treatments have the potential to affect local populations through direct mortality depending on the season, type, and size of treatment. The scale of invertebrate habitats and population sizes can vary by orders of magnitude compared with vertebrates. Although some invertebrate species are noted for their explosive population numbers, many invertebrate species are scarce and recognized as threatened, endangered, or of conservation concern (for example, LaBonte and others 2001). One of the inherent problems in planning fuel reduction treatments, however, is the lack of information available about this highly diverse group.

Relatively few studies have evaluated the effects of fuel reduction treatments on invertebrates in dry coniferous forests. These studies focused variously on communities of certain strata (for example, forest litter or soil) or certain taxa (for example, spiders, ground beetles, butterflies, bark beetles). In this synthesis, we organize available information to the extent possible around functional groups (detritivores, predators, forest herbivores, and pollinators) described in Niwa and others (2001b). For the ponderosa pine forests of the Southwest, Short and Negron (2003) examine pertinent literature and predict arthropod responses across a similar array of functional groups to forest restoration activities including mechanical thinning, prescribed burning, and thinning with burning. In most experimental studies, numerical and in some cases functional responses to treatments have been measured by using census or survey techniques expressed in terms of abundance and diversity (species assemblages, richness, evenness). An increasing number of studies are examining mechanisms and consequences of disturbance including fuel reduction treatments on invertebrate communities and habitat dynamics. A number of studies have focused on bark or wood boring insects, because of their well-known relation with site disturbance and host stress, and the large-scale disturbance and disruption of management objectives that outbreaks can cause (see syntheses by Filip and others 1996; Gast and others 1991; Hayes and Daterman 2001). We treat this group separately.

The threat to forest health posed by outbreaks of native species, particularly insects like some species of bark beetles and defoliators, is somewhat unique to invertebrates. Silvicultural practices (such as precommercial thinning) that improve growing conditions of desired tree species and stand health have long been considered one means of reducing the risk and impact of these disturbance agents (Gast and others 1991). However, the direct use of fuel reduction treatments to achieve the combined goal of fuel and insect management has not been widely applied or extensively studied, with one exception being slash (thinning residue) treatments that are aimed at reducing surface fuel and the build-up of populations of some bark and woodboring insects (for example, Six and others 2002; Zabowski and others 2000). The success of fuel reduction treatments as insect population control tactics, through habitat alteration or direct mortality, requires an understanding of potential life history or behavioral vulnerabilities of the species, population dynamics, and season of treatment application, particularly in the cases of prescribed fire (for example, McCullough and others 1998; Miller 1979). For example, microclimate changes in thinned stands have been found to affect mountain pine beetle (Dendroctonus ponderosae) behavior and colonization of ponderosa and lodgepole pine (reviewed in Amman and Logan 1998). Fuel reduction treatments may also have important implications for the management of nonnative invasive invertebrate species, and some specific examples with variable results have been reported in other ecosystems (for example, Callaham and others 2003; Sanders 2004; Zettler and others 2003).

Our lack of knowledge about the diverse invertebrate communities of dry coniferous forests is a significant limitation in understanding and predicting the response of this group, native and nonnative, to fuel reduction treatments. Across invertebrate groups and for diverse ecosystems, the provision of refugia (leaving untreated areas from which populations can recolonize) is widely recommended to minimize the effects of direct mortality and accelerate recovery (for example, Hohenlohe and Duncan 2003; Panzer 2003). Based on studies in boreal forests, but seemingly generally applicable, Niemela (1999) concluded that recovery will be influenced by treatment size, by retention of critical habitat components such as coarse woody debris, and by size, amount and distance between these refugia.

\section{Detritivores}

Invertebrates of the forest soil and floor are instrumental in decomposition and nutrient cycling and include detritivores (such as earthworms, land snails and slugs, and arthropods including millipedes, isopods, mites, and springtails) and those species actively involved in the decomposition of dead vegetation including down wood and snags (such as termites, 
beetles, and ants). Although Niwa and others (2001a, b) and Short and Negron (2003) review the potential effects of management activities, including thinning and prescribed fire, on invertebrates of the soil, litter, and down wood in western dry coniferous forests, few studies have specifically examined the effects of fuel reduction treatments on detritivores and decomposers in these forests. As has been shown elsewhere (Battigelli and others 2004; Gunnarsson and others 2004), Niwa and others (2001a, b) and Short and Negron (2003) hypothesized that thinning is likely to have a substantial negative effect, at least in the short-term, on invertebrates of the soils and organic layers through soil compaction and disruption or loss of organic layers. Compaction will depend on soil type and thinning mechanism. Soil organisms may be more buffered from the effects of treatments than those in the litter layers. For example, long-term effects of thinning (16-41 years posttreatment) on densities of microinvertebrates (including oribatid, mesotigmid, and prostigmatid mites) were found in the litter of late-successional white fir (Abies concolor) and Douglas-fir forests in the Cascade Mountains of southwestern Oregon, but no differences were found in mite or Collembola densities in the upper $5 \mathrm{~cm}$ of soil between thinned and unthinned stands (Peck and Niwa 2004).

Prescribed fire effects on the inhabitants of forest soil, litter, and down wood may differ dramatically by species, but are likely to depend on fire intensity (Niwa and others 2001a, b). In ponderosa pine stands in Blacks Mountain Experimental Forest in northeastern California, preliminary results show that low-intensity prescribed fire had little effect on the species richness, diversity, and evenness of oribatid mites whereas moderate-intensity prescribed fires substantially affected mite community structure (Oliver 2000). Tenebrionid beetles, which are forest floor scavengers, were found at higher richness and diversity in ponderosa pine stands of northern Arizona seven to eight years after wildfire and 13 to 14 years after fuel reduction treatments (thinning alone and thinning with prescribed burning) compared to untreated stands (Chen et al. 2006). Studies in other ecosystems have shown fuel reduction treatments can negatively affect invertebrates of the soil and litter directly through mortality and loss of food and cover, and many have prolonged recovery periods (for example, Hanula and Wade 2003; Springett 1976). Information on effects of changes in soil and litter invertebrates on ecosystem functions (for example, nutrient cycling) is needed.

\section{Predators}

Predatory invertebrates can be found throughout forest habitats, but frequently studied predators are those of the forest floor, especially spiders and carabid beetles. These invertebrates are likely to recoverfrom fuel reduction treatments more quickly than those in the soil, particularly those with greater mobility and dispersal ranges. They may also respond positively to greater habitat heterogeneity created by treatments. Two studies, one on response to thinning $(>16$ years posttreatment) and the other on prescribed fire ( $<1$ to 15 years posttreatment), focused on spiders and carabid beetles in late-successional white fir and Douglas-fir forests in the Cascade (Peck and Niwa 2004) and Klamath Mountains of Oregon (Niwa and Peck 2002). Although no difference was found in overall abundance or species richness of carabid beetles between thinned and unthinned stands, some individual species were more or less abundant in thinned stands. Abundance and species richness of spiders were significantly higher in thinned stands. Generally, hunting spiders were more numerous in thinned stands, whereas sheet web-building spiders were more numerous in unthinned stands (see also McIver and others 1992).

In their study of short- to long-term effects of prescribed fire, Niwa and Peck (2002) found no differences in species richness or diversity for carabids or spiders. However, four of five common species of carabids were more abundant in unburned sites. Four of seven common spider species were more abundant in unburned sites, and three were more abundant in burned sites. As was found with thinning treatments, hunting spiders were more abundant in treated sites, and web-builders were more abundant in untreated sites. Only a weak relationship was found between abundance and time since burn. Patterns were likely influenced by differences in fire intensities among years (Niwa and Peck 2002).

Site management history and size of treatment area were factors considered important in moderating changes in diversity and abundance of leaflitter arthropods in mixed-conifer stands in the Sierra Nevada Mountains of California one year following fire and fire surrogate treatments (prescribed burning, overstory thinning with understory mastication, and combined thinning and burning) (Apigian and others 2006). Apigian and others (2006) found species richness of ground beetles was slightly higher in burned compartments. However, changes in abundance due to treatments were taxon-specific among common groups of beetles, ants, and spiders and showed no particular pattern. In a longer-term study of ground beetles in ponderosa pine stands of northern Arizona, the species assemblage did not vary between thinned (4-10 years posttreatment) and untreated stands, was richer in thinned stands that were subsequently (3-4 years) treated with prescribed fire, and was highest in stands two years following wildfire (Villa-Castillo and Wagner 2002). These authors attribute the high diversity in burned stands to temporary colonization by open-area species, pyrophilous species, and the beginning of recolonization from refugia. In another study conducted in ponderosa pine stands in northern Arizona, Chen et al. (2006) found consistently higher richness and diversity of carabids more than seven years following wildfire and more than 13 years following fuel treatments. They conclude that carabids may provide a useful indicator of ponderosa pine stand conditions following fuel treatments or wildfire.

\section{Forest Herbivores and Pollinators}

Depending on the timing of fuel reduction treatments, invertebrate herbivores and pollinators such as moths and butterflies that feed on and live in live vegetation during some life stage can be immediately affected through direct 
mortality or loss of food or cover. In the long-term, these invertebrates may benefit from changes in structural diversity caused by fuel reduction treatments that increase the amount of light reaching foliage and the forest floor. Two years after a thinning that removed 50 percent of the basal area in young ponderosa pine in central Oregon, abundance of pandora moths (Coloradia pandora) (which feed as larvae on pine foliage) was not affected (Ross 1995). However, adult emergence and egg hatch occurred seven to 10 days earlier in thinned stands, presumably as a result of increased solar radiation and temperature (Ross 1995). In ponderosa pine/ oak forest type in northern Arizona, Waltz and Covington (2004) found that adult butterfly abundance and species richness were greater with a combination of thinning and prescribed fire than were those of paired control sites. They found these elevated responses up to two years posttreatment corresponded with significantly greater light intensity in the treated site, although larval host and nectar plant richness did not change. Similar results were reported by Huntzinger (2003) after prescribed fire ( 1 to $>15$ years) in two forest types (late-successional reserve Douglas-fir and hardwoods in the Siskiyou Mountains of Oregon and mid- to late-seral pines and firs in western Sierra Nevadas of California). Huntzinger (2003) found adult butterfly species richness and diversity were significantly greater in burned sites (including upland forest sites, riparian sites, and fuel breaks) than in control sites. As found by Waltz and Covington (2004), penetration of sunlight (total area and density of sunlit patches) was found to be a significant factor in butterfly species richness (Huntzinger 2003). Additionally, Huntzinger (2003) called attention to the potential for nonnative plant species invasion following prescribed fire and other disturbances that could have secondary negative impacts through loss of host plants (but see Forrester and others 2005).

\section{Bark and Wood Boring Insects}

Species benefiting from stress or weakened defenses of living hosts, such as root and bark beetles and wood borers, are likely to respond positively in the short-term to site disturbance created by thinning and prescribed fire, although timing of treatment affects the response. Machmer (2002) found a substantial increase in abundance of some bark beetles and wood borers (families in the Coleoptera and Hymenoptera) after prescribed fire only (170 percent increase), partial harvest and prescribed fire (54 percent increase), and partial harvest only (45 percent increase) compared to untreated controls (up to one year posttreatment) in interior Douglas-fir and ponderosa pine stands in British Columbia. They also reported an increase in diversity of beetles within the flat-headed wood borers (Buprestidae), round-headed wood borers (Cerambycidae), and bark beetles (Curculionidae: Scolytinae). Apigian and others (2006) also found bark and woodboring beetles (including scolytids: Hylurgops spp., Hylastes spp., and Xyleborus spp.) increased in the year following thinning and prescribed fire, which is common (for example, Hanula and others 2002; Sullivan and others 2003; Witcosky 1986).
Several studies examining effects of prescribed fire on bark and wood boring beetles found comparable results. Low-intensity late-season prescribed fire in Jeffrey pine stands in the Sierra Nevadas resulted in a greater number of trees attacked by bark beetles (Scolytinae: Dendroctonus and Ips spp.) compared to untreated stands (Bradley and Tueller 2001). Crown and bole scorch were significant predictors of beetle presence in fire-injured trees. In an experiment where lodgepole pine boles were burned prior to mountain pine beetle flight in Banff and Kootenay National Parks, Elkin and Reid (2004) found that emerging beetles did not preferentially attack fire-injured trees. However, attack success was higher in injured trees when beetle population levels were low; at high population levels, injured and uninjured trees were equally likely to be successfully attacked.

Three studies examined short- and long-term effects of fuel reduction treatments on bark and wood boring beetles in ponderosa pine in northern Arizona. McHugh and others (2003) followed tree mortality and beetle attacks for three years after a spring and summer wildfire and a fall prescribed fire. They found wood boring beetle colonization and bark beetle attacks were highest in the first year postfire (wildland or prescribed). Trees attacked by bark beetles had more crown injury than unattacked trees; attack percentage was highest in the spring burn and lowest in the fall burn. Wallin and others (2003) found a positive relationship between crown scorch and attempted bark beetle colonization in a study examining responses of host trees and bark beetle populations after treatment (winter/ spring prescribed fire with thinning). Over a three-year period, Sanchez-Martinez and Wagner (2002) found low population levels of endemic bark beetles regardless of treatment history (that is, no evidence of an outbreak); these treatments included untreated, thinned (4-11 years prior), thinned followed by prescribed fire within three to four years, or stand replacement by wildfire (two years prior). These results are counter to the hypothesis that dense stands should be more susceptible to beetle infestation (Sanchez-Martinez and Wagner 2002).

\section{Summary}

This synthesis provides a current state of knowledge and elucidates the many data gaps that exist on the effects of fuel reduction on fauna in dry coniferous forest types in the West. Effects of fuel reduction on wildlife and invertebrate species differ according to a number of factors that may differ with each thinning or prescribed fire treatment, including current condition and management history, existing and surrounding habitats, landscape setting, and treatment attributes (type, size, season, frequency). This confounds our ability to generalize about responses to fuel treatments and limits predictions to those species that are well-studied and have responded consistently to various fuel reduction treatments. In general, species preferring open habitats and species associated with early successional vegetation will likely benefit from fuel reduction treatments whereas those species that prefer closed canopy forests or dense understory will likely be negatively 
affected by fuel reductions. Species that are closely associated with those habitat elements that will be removed or consumed by fuel reductions (such as down wood, large-diameter snags, small diameter trees, and shrubs) will experience habitat loss, at least in the short term.

Wildlife and invertebrate populations have evolved with fire as a natural disturbance in dry forests of the West, and thus hazardous fuel reductions that simulate historical fire regimes may ultimately benefit some native fauna. Managing fuels to recreate natural disturbance patterns (Bunnell 1995; Allen and others 2002) and to reduce the risk of catastrophic fires can be done in a conservative, incremental manner using mechanical thinning and fire over a long time period for restoration of ecosystems (Allen and others 2002). This concept may allow managers to move away from single-species management and toward ecosystem management. Nonetheless, long-term monitoring of invertebrate and wildlife populations will ultimately determine whether frequent, repeated thinning and prescribed fire is having beneficial or adverse effects on species of interest.

There is a great need for long-term observational and preferably experimental studies on the effects of a range of fuel reduction treatments at multiple spatial scales (stand or larger). Ideally, replicated before-after-control-impact studies, such as those underway with the Fire and Fire Surrogate Program and Bird and Burns Network, will provide much needed information. However, until more complete information on many species becomes available, the consideration of management activities that allow the retention of critical habitat elements is warranted, particularly those that are slow to recover such as large-diameter down wood and snags.

\section{English Equivalents}

\begin{tabular}{lcl}
\hline When you know: & Multiply by: & To find: \\
\hline Centimeters (cm) & 0.39 & Inches \\
Meters (m) & 3.28 & Feet \\
Kilometers (km) & 0.62 & Miles \\
Hectares (ha) & 2.47 & Acres \\
\hline
\end{tabular}

\section{References}

Agee, J.K. 1993. Fire ecology of the Pacific Northwest. Washington, DC: Island Press. 493 p.

Ahlgren,C.E. 1966. Small mammals and reforestation following prescribed burning. Journal of Forestry. 64: 614-618.

Allen, C.D.; Savage, M.; Falk, D.A.; Suchling, K.F.; Swetnam, T.W.; Schulke, T.; Stacey, P.B.; Morgan, P.; Hoffman, M.; Klingel, J.T. 2002. Ecological restoration of southwestern ponderosa pine ecosystems: a broad perspective. Ecological Applications. 12: 1418-1433.

Altman, B.; Sallabanks, R. 2000. Olive-sided flycatcher (Contopus cooperi). In: Poole, A.; Gill, F., eds. The birds of North America No. 502. Philadelphia, PA: The Academy of Natural Sciences; Washington, DC: American Ornithologists' Union. 28 p.
Amman, G.D.; Logan, J.A. 1998. Silvicultural control of mountain pine beetle: prescriptions and the influence of microclimate. American Entomologist. 44: 166-178.

Anderson, S.H.; Crompton, B.J. 2002. The effects of shelterwood logging on bird community composition in the Black Hills, Wyoming. Forest Science. 48: 365-372.

Apigian, K.O.; Dahlsten, D.L.; Stephens, S.L. 2006. Fire and fire surrogate treatment effects on leaf litter arthropods in a western Sierra Nevada mixed-conifer forest. Forest Ecology and Management. 221: 110-122.

Artman, V.L.; Sutherland, E.K.; Downhower, J.F. 2001. Prescribed burning to restore mixed-oak communities in southern Ohio: effects on breeding bird populations. Conservation Biology. 15: 1423-1434.

August, P.V. 1983. The role of habitat complexity and heterogeneity in structuring tropical mammal communities. Ecology. 64: 1495-1507.

Ausband, D.E.; Baty, G.R. 2005. Effects of precommercial thinning on snowshoe hare habitat use during winter in low-elevation montane forests. Canadian Journal of Forest Research. 35: 1-5.

Babbitt, L.H.; Babbitt, C.H. 1951. A herpetological study of burned-over areas in Dade County, Florida. Copeia. 1951: 79.

Bate, L.J. 1995. Monitoring woodpecker abundance and habitat in the central Oregon Cascades. Moscow, ID: University of Idaho. 116 p. Thesis.

Battigelli, J.P.; Spence, J.R.; Langor, D.W.; Berch, S.M. 2004. Short-term impact of forest soil compaction and organic matter removal on soil mesofauna density and oribatid mite diversity. Canadian Journal of Forest Research. 34: 1136-1149.

Beier, P.; Maschinski, J. 2003. Threatened, endangered, and sensitive species. In: Friederici, P., ed. Ecological restoration of Southwestern ponderosa pine forests. Washington, DC: Island Press: 306-327.

Belsky, A.J.; Blumenthal, D.M. 1997. Effects of livestock grazing on stand dynamics and soils in upland forests of the interior West. Conservation Biology. 11: 315-327.

Bentz, J.A.; Woodard, P.M. 1988. Vegetation characteristics and bighorn sheep use on burned and unburned areas in Alberta. Wildlife Society Bulletin. 16: 186-193.

Betts, B.J. 1998. Roost use by maturity colonies of silverhaired bats in northeastern Oregon. Journal of Mammalogy. 79: 643-650.

Black, H.C.; Hooven, E.F. 1974. Response of small mammal communities to habitat changes in western Oregon. In: Black, H.C., ed. Wildlife and forest management in the Pacific Northwest; proceedings of a symposium; 1973 September 11-12. Corvallis, OR: Oregon State University: 177-186.

Bock, C.E.; Block, W.M. 2005. Fire and birds in the southwestern United States. Studies in Avian Ecology. 30: 14-32.

Bock, C.E.; Bock, J.H. 1983. Responses of birds and deer mice to prescribed burning in ponderosa pine. Journal of Wildlife Management. 47: 836-840. 
Boyles, J.G.; Aubrey, D.P. 2006. Managing forests with prescribed fire: implications for a cavity-dwelling bat species. Forest Ecology and Management. 222: 108-115.

Bradley, T.; Tueller, P. 2001. Effects of fire on bark beetle presence on Jeffery pine in the Lake Tahoe Basin. Forest Ecology and Management. 142: 205-214.

Brawn, J.D.; Balda, R.P. 1988. The influence of silvicultural activity on ponderosa pine forest bird communities in the southwestern United States. Bird Conservation. 3: 3-21.

Brisson, J.A.; Strasburg, J.L.; Templeton, A.R. 2003. Impact of fire management on the ecology of collared lizard (Crotaphytus collaris) populations living in the Ozark Plateau. Animal Conservation. 6: 247-254.

Brown, R. 2000. Thinning, fire and forestrestoration: a sciencebased approach for national forests in the Interior Northwest. Washington, DC: Defenders of Wildlife. 39 p.

Brown, R.; Agee, J.K.; Franklin, J.F. 2004. Forest restoration and fire: principles in the context of place. Conservation Biology. 18: 903-912.

Brown, J.K.; Smith, J.K., eds. 2000. Wildland fire in ecosystems: effects of fire on flora. Gen. Tech. Rep. RMRS-GTR42, Vol. 2. Ogden, UT: U.S. Department of Agriculture, Forest Service, Rocky Mountain Research Station. 257 p.

Bull, E.L. 1986. Resource partitioning among woodpeckers in northeast Oregon. Moscow: University of Idaho. 109 p. Dissertation.

Bull,E.L. 1987. Ecology of the pileated woodpecker in northeastern Oregon. Journal of Wildlife Management. 51: 472-481.

Bull, E.L.; Akenson, J.J.; Henjum, M.G. 2000. Characteristics of black bear dens in trees and logs in northeastern Oregon. Northwest Science. 81: 148-153.

Bull, E.L. In press. Sexual differences in the ecology and habitat selection of western toads (Bufo boreas) in northeastern Oregon. Herpetological Conservation and Biology.

Bull, E.L.; Blumton, A.K. 1999. Effect of fuels reduction on American Marten and their prey. Res. Note PNW-RN539. Portland, OR: U.S. Department of Agriculture, Forest Service, Pacific Northwest Research Station. 10 p.

Bull, E.L.; Clark, A.A.; Shepherd, J.F. 2005a. Short-term effects of fuel reduction on pileated woodpeckers in northeastern Oregon-a pilot study. Res. Pap. PNW-RP564. Portland, OR: U.S. Department of Agriculture, Forest Service, Pacific Northwest Research Station. 17 p.

Bull, E.L.; Heater, T.W.; Clark, A.A.; Shepherd, J.F.; Blumton, A.K. 2005b. Influence of precommercial thinning on snowshoe hares. Res. Pap. PNW-RP-562. Portland, OR: U.S. Department of Agriculture, Forest Service, Pacific Northwest Research Station. 16 p.

Bull, E.L.; Heater, T.W.; Shepherd, J.F. 2005c. Habitat selection by the American marten in northeastern Oregon. Northwest Science. 79: 37-43.

Bull, E.L.; Heater, T.W.; Wertz, T. L. 2001a. Black bear habitat use in northeastern Oregon. Western Black Bear Workshop. 7: 82-91.
Bull, E.L.; Heater, T.W.; Youngblood, A. 2004. Arboreal squirrel response to silvicultural treatments for dwarf mistletoe control in northeastern Oregon. Western Journal of Applied Forestry. 19: 133-141.

Bull, E.L.; Parks, C.G.; Torgersen, T.R. 1997. Trees and logs important to wildlife in the interior Columbia River basin. Gen. Tech. Rep. PNW-GTR-391. Portland, OR: U.S. Department of Agriculture, Forest Service, Pacific Northwest Research Station. 56 p.

Bull, E.L.; Torgersen, T.R.; Wertz, T.L. 2001b. The importance of vegetation, insects, and neonate ungulates in black bear diet in Northeastern Oregon. Northwest Science. 75: 244-253.

Bunnell, F.L.1995. Forest-dwelling vertebrate faunas and natural fire regimes in British Columbia: patterns and implications for conservation. Conservation Biology. 9: 636-644.

Bunnell, F.L.; Kremsater, L.L.; Wind, E. 1999. Managing to sustain vertebrate richness in forests of the Pacific Northwest: relationships within stands. Environmental Review. 97: 97-146.

Bury, R.B. 2004. Wildfire, fuel reduction, and herpetofauna across diverse landscape mosaics in northwestern forests. Conservation Biology. 18: 968-975.

Bury, R.B.; Corn, P.S. 1988. Responses of aquatic and streamside amphibians to timber harvest: a review. In: Raedeke, K.J., ed. Streamside management: riparian, wildlife and forestry interactions. Institute of Forest Research. 59: 165-181.

Bury, R.B.; Major, D.J.; Pilliod, D.S. 2002. Responses of amphibians to fire disturbance in Pacific Northwest forests: a review. In: Ford, W.M.; Russell, K.R.; Moorman, C.E., eds. The role of fire in nongame wildlife management and community restoration: traditional uses and new directions. Gen. Tech. Rep. NE-GTR-288. Newtown, Square, PA: U.S. Department of Agriculture, Forest Service, Northeastern Research Station: 34-42.

Callaham, M.A., Jr.; Blair, J.M.; Todd, T.C.; Kitchen, D.J.; Whiles, M.R. 2003. Macroinvertebrates in North American tallgrass prairie soils: effects of fire, mowing, and fertilization on density and biomass. Soil Biology and Biochemistry. 35: 1079-1093.

Campbell, T.M., III; Clark, T.W. 1980. Short-term effects of logging on red-backed voles and deermice. Great Basin Naturalist. 40: 183-189.

Canon, S.K.; Urness, P.J.; DeByle, N.V. 1987. Habitat selection, foraging behavior, and dietary nutrition of elk in burned aspen forest. Journal of Range Management. 40: 433-438.

Carey, A.B. 2001. Experimental manipulation of spatial heterogeneity in Douglas-fir forest: effects on squirrels. Forest Ecology and Management. 152: 13-30.

Carey, A.B. 2002. Response of northern flying squirrels to supplementary dens. Wildlife Society Bulletin. 30: 547-556. 
Carey, A.B. 2003. Restoration of landscape function: reserves or active management? Forestry. 76: 221-230

Carey, A.B.; Lippke, B.R.; Sessions, J. 1999a. Intentional systems management: managing forests for biodiversity. Journal Sustainable Forestry. 9:83-125.

Carey, A.B.; Maguire, C.C.; Biswell, B.L.; Wilson, T.M. 1999b. Distribution and abundance of Neotoma in Western Oregon and Washington. Northwest Science. 73: 65-79.

Carey, A.B.; Wilson, S.M. 2001. Induced spatial heterogeneity in forest canopies: responses of small mammals. Journal Wildlife Management. 65: 1014-102.

Carey, H.; Schumann, M. 2003. Modifying wildfire behavior-the effectiveness of fuel treatments. Southwest Region Working Paper 2. Santa Fe, NM: National Community Forestry Center. $26 \mathrm{p}$.

Chambers, C.L. 2002. Forest management and the dead wood resource in ponderosa pine forests: effects on small mammals. In: Laudenslayer Jr., W.F., and others, technical coordinators. Proceedings of the symposium on the ecology and management of dead wood in western forests. Gen. Tech. Rep. PSW-GTR-181. Albany, CA: U.S. Department of Agriculture, Forest Service, Pacific Southwest Research Station: 679-693.

Chambers, C.L.; Alm, V.; Sider, M.S.; Rabe, M.J. 2002. Use of artificial roosts by forest-dwelling bats in northern Arizona. Wildlife Society Bulletin. 30: 1085-1091.

Chambers, C.L.; Germaine, S.S. 2003. Vertebrates. In: Friederici, P., ed. Ecological restoration of Southwestern ponderosa pine forests. Washington, DC: Island Press: 268-285.

Chambers, C.L.; Mast, J.N. 2005. Ponderosa pine snag dynamics and cavity excavation following wildfire in northern Arizona. Forest Ecology and Management. 216: 227-240.

Chen, Z.; Grady, K.; Stephens, S.; Villa-Castillo, J.; Wagner, M.R. 2006. Fuel reduction treatment and wildfire influence on carabid and tenebrionid community assemblages in the ponderosa pine forest of northern Arizona, USA. Forest Ecology and Management. 225: 168-177.

Clewell, A.; Rieger, J.; Munro, J. 2005. Society for Ecological Restoration International: Guidelines for developing and managing ecological restoration projects, 2 nd edition. Tuscon, AZ: Society for Ecological Restoration International. $16 \mathrm{p}$.

Cole, E.C.; McComb, W.C.; Newton, M.; Chambers, C.L.; Leeming, J.P. 1997. Response of amphibians to clearcutting, burning, and glyphosate application in the Oregon Coast Range. Journal of Wildlife Management. 61: 656-664.

Constible, J.M.; Gregory, P.T.; Anholt, B.R. 2001. Patterns of distribution, relative abundance, and microhabitat use of anurans in a boreal landscape influenced by fire and timber harvest. Ecoscience. 8: 462-470.

Corn, P.S.; Bury, R.B. 1989. Logging in western Oregon: responses of headwater habitats and stream amphibians. Forest Ecology and Management. 29: 119.
Corn, P.S.; Hossack, B.R. [n.d.]. Unpublished data on file at U.S. Department of Agriculture, Forest Service, Rocky Mountain Research Station, Aldo Leopold Wilderness Institute, Missoula, MT.

Covington, W.W.; Moore, M.M. 1994. Southwestern ponderosa forest structure: Changes since Euro-American settlement. Journal of Forestry. 92:39-47.

Cunningham, S.C.; Babb, R.D.; Jones, T.R.; Taubert B.D.; Vega, R. 2002. Reaction of lizard populations to a catastrophic wildfire in a central Arizona mountain range. Biological Conservation. 107: 193-201.

DeBano, L.F.; Neary, D.G.; Ffolliott, P.F. 1998. Fire's effects on ecosystems. New York: John Wiley and Sons. 333 p.

DeGraaf, R.M.; Healy, W.M.; Brooks, R.T. 1991. Effects of thinning and deer browsing on breeding birds in New England oak woodlands. Forest Ecology and Management. 41: 179-191.

Demarais, S.; Krausman, P.R. 2000. Ecology and management of large mammals in North America. Upper Saddle River, NJ: Prentice Hall. 778 p.

deMaynadier; P.G.; Hunter, M.L., Jr. 1995. The relationship between forest management and amphibian ecology: a review of the North American literature. Environmental Review. 3: 230-261.

DePerno, C.S.; Jenks, J.A.; Griffin, S.L.; Rice, L.A.; Higgins, K.F. 2002. White-tailed deer habitats in the central Black Hills. Journal of Range Management. 55: 242-252.

Dickson, J.G. 1981. Effects of forest burning on songbirds. In: Wood, G.W., ed. Prescribed fire and wildlife in southern forests. Georgetown, SC: Clemson University, The Belle W. Baruch Forest Science Institute: 67-72.

Dimock, E.J., II. 1974. Animal populations and damage. In: Cramer, O.P., ed. Environmental effects of forest residues management in the Pacific Northwest. Gen. Tech. Rep. GTRPNW-24. Portland, OR: U.S. Department of Agriculture, Forest Service, Pacific Northwest Research Station: 1-28.

Dixon, R.D. 1995. Ecology of white-headed woodpeckers in the central Oregon Cascades. Moscow: University of Idaho. 148 p. Thesis.

Dodd, N.L.; States, J.S.; Rosenstock, S.S. 2003. Tasseleared squirrel population, habitat condition, and dietary relationships in north-central Arizona. Journal of Wildlife Management. 67: 622-633.

Dwire, K.A.; Ryan, S.E.; Shirley, L.J.; Lytjen, D.; Otting, N.; Dixon, M.K. 2006. Influence of herbivory on regrowth of riparian shrubs following a wildland fire. Journal of the American Water Resources Association (JAWRA). 42: 201-212.

Easterly, T.G.; Jenkins, K.J. 1991. Forage production and use on bighorn sheep winter range following spring burning in grassland and ponderosa pine habitats. Prairie Naturalist. 23: 193-200.

Easton, W.E.; Martin, K. 2002. Effects of thinning and herbicide treatments on nest-site selection by songbirds in young managed forests. Auk. 119: 685-694. 
Edge, D.W.; Marcum, C.L.; Oslon-Edge, S.L. 1987. Summer habitat selection by elk in western Montana: a multivariate approach. Journal of Wildlife Management. 51: 844-851.

Elkin, C.M.; Reid, M.L. 2004. Attack and reproductive success of mountain pine beetles (Coleoptera: Scolytidae) in fire-damaged lodgepole pine. Environmental Entomology. 33: $1070-1080$.

Elliot, W.J.; Page-Dumroese, D.; Robichaud, P.R. 1999. The effects of forest management on erosion and soil productivity. In: Lal, R., ed. Soil quality and soil erosion. Boca Raton, FL: CRC Press: 195-208.

Esque, T.C.; Schwalbe, C.R.; DeFalco, L.A.; Duncan, R.B.; Hughes, T.J. 2003. Effects of wild fire on small desert vertebrates, especially desert tortoise (Gopherus agassizii). The Southwestern Naturalist. 48: 103-111.

Everett, R.; Schellhaus, D.; Spurbeck, D.; Ohlson, P.; Kechum, D.; Anderson, T. 1997. Structure of northern spotted owl nest stands and their historical conditions on the eastern slope of the Pacific Northwest Cascades, USA. Forest Ecology and Management. 94: 1-14.

Filip, G.M.; Torgersen, T.R.; Parks, C.G.; Mason, R.R.; Wickman, B. 1996. Insects and disease factors in the Blue Mountains. In: Jaindl, R.G.; Quigley, T.M., eds. Search for a solution: sustaining the land, people, and economy of the Blue Mountains. Washington, DC: American Forests: 169-202.

Finch, D.M.; Ganey, J.L.; Yong, W.; Kimball, R.T.; Sallabanks, R. 1997. Effects and interactions of fire, logging, and grazing. In: Block, W.M.; Finch, D.M., eds. Songbird ecology in Southwestern ponderosa pine forests: a literature review. Gen. Tech. Rep. RM-GTR-292. Fort Collins, CO: U.S. Department of Agriculture, Forest Service, Rocky Mountain Forest and Range Experiment Station: 103-136.

Finn, S.P.; Verland, D.E.; Marzluff, J.M. 2002. Does northern goshawk breeding occupancy vary with nest-stand characteristics on the Olympic Peninsula, Washington? Journal of Raptor Research. 36: 265-279.

Fisher, J.T.; Wilkinson, L. 2005. The response of mammals to forest fire and timber harvest in the North American boreal forest. Mammal Review. 35: 51-81.

Folk, R.H., III; Bales, C.W. 1982. An evaluation of wildlife mortality resulting from aerial ignition prescribed burning. Proceedings Annual Conference Southeastern Association Fish and Wildlife Agencies. 36: 643-646.

Ford, W.M.; Menzel, M.A.; McGill, D.W.; Laerm, J.; McCay, T.S. 1999. Effects of a community restoration fire on small mammals and herpetofauna in the southern Appalachians. Forest Ecology and Management. 114: 233-243.

Forrester, J.A.; Leopold, D.J.; Hafner, S.D. 2005. Maintaining critical habitat in a heavily managed landscape: effects of power line corridor management on Karner blue butterfly (Lycaeides Melissa samuelis) habitat. Restoration Ecology. 13: 488-498.
Frenzel, R.W. 2004. Nest-site occupancy, nesting success, and turnover-rates of white-headed woodpeckers in the Oregon Cascade Mountains in 2004. Unpublished paper on file with: Richard W. Frenzel, 12330 S.E. Reedway Street, Portland, OR 97236.

Gaines, W.L.; Lehmkuhl, J.F.; Lyons, A.L.; Harrod, R.J. [In press]. Short-term response of land birds to ponderosa pine restoration. Restoration Ecology.

Gamradt, S.C.; Kats, L.B. 1997. Impact of chaparral wildfire-induced sedimentation on oviposition of streambreeding California new ts (Taricha torosa). Oecologica. 110: 546-549.

Gast, W.R., Jr.; Scott, D.W.; Schmitt, C.; Clemens, D.; Howes, S.; Johnson, C.G., Jr.; Mason, R.; Mohr, F.; Clapp, R.A., Jr. 1991. Blue Mountains forest health report: new perspectives in forest health. U.S. Department of Agriculture, Forest Service, Malheur, Umatilla, and Wallowa-Whitman National Forests. [Unconventional pagination].

George, T.L.; Zack, S. 2001. Spatial and temporal consideration in restoring habitat for wildlife. Restoration Ecology. 9: 272-279.

Germaine, H.L.; Germaine, S.S. 2002. Forest restoration treatment effects on the nesting success of western bluebirds (Sailia mexicana). Restoration Ecology. 110: 362-367.

Germaine, S.S.; Germaine, H.L. 2002. Lizard distributions and reproductive success in a ponderosa pine forest. Journal of Herpetology. 37: 645-652.

Germaine, S.S.; Germaine, H.L.; Boe, S.R. 2004. Characteristics of mule deer day-bed and forage sites in current condition and restoration-treated ponderosa pine forest. Wildlife Society Bulletin. 32: 554-564.

Gillespie, G.R. 2002. Impacts of sediment loads, tadpole density, and food type on the growth and development of tadpoles of the spotted tree frog Litoria spenceri: an in-stream experiment. Biological Conservation. 106: 141-150.

Goodwin, J.G., Jr.; Hungerford, C.R. 1979. Rodent population densities and food habits in Arizona ponderosa pine forests. Res. Pap. RM-214. Fort Collins, CO: U.S. Department of Agriculture, Forest Service, Rocky Mountain Forest and Range Experimental Station. 12 p.

Graham, R.T.; McCaffrey, S.; Jain, T.B. 2004. Science basis for changing forest structure to modify wildfire behavior and severity. Gen. Tech. Rep. RMRS-GTR-120. Fort Collins, CO: U.S. Department of Agriculture, Forest Service, Rocky Mountain Research Station. 43 p.

Griffiths, A.D.; Christian, K.A. 1996. The effect of fire on the frillneck lizard (Chlamydosaurus kingii) in northern Australia. Australian Journal of Ecology. 21: 386-398.

Gunnarsson, B.; Nitterus, K.; Wirdenas, P. 2004. Effects of logging residue removal on ground-active beetles in temperate forests. Forest Ecology and Management. 201: 229-239.

Hagar, J.C.; McComb, W.C.; Emmingham, W.H. 1996. Bird communities in commercially thinned and unthinned Douglas-fir stands of western Oregon. Wildlife Society Bulletin. 24: 353-366. 
Hamilton, R.J. 1981. Effects of prescribed fire on black bear populations in southern forests. In: Wood, G.W., ed. Prescribed fire and wildlife in southern forests. Georgetown, SC: Clemson University, The Belle W. Baruch Forest Science Institute: 129-134.

Hann, W.J.; Jones, J.L.; Karl, M.G.; Hessburg, P.F.; Keane, R.E.; Long, D.G.; Menakis, J.P.; McNicoll, C.H.; Leonard, S.G.; Gravenmier, R.A.; Smith, B.G. 1997. Landscape dynamics of the basin. In: Quigley, T.M.; Arbelbide, S.J., tech. eds. An assessment of ecosystem components in the interior Columbia Basin and portions of the Klamath and Great Basins. Gen. Tech. Rep. PNW-GTR-405. Portland, OR: U.S. Department of Agriculture, Forest Service, Pacific Northwest Research Station: 337-1055.

Hannon, S.J.; Drapeau, P. 2005. Bird responses to burning and logging in the boreal forest of Canada. Studies in Avian Biology. 30: 97-115.

Hanson, E.E. 1978. The impact of prescribed burn in a temperate subalpine forest upon the breeding bird and small mammal populations. Ellensburg, WA: Central Washington University. 56 p. Thesis.

Hanula, J.L.; Meeker, J.R.; Miller, D.R.; Barnard, E.L. 2002. Association of wildfire with tree health and numbers of pine bark beetles, reproduction weevils and their associates in Florida. Forest Ecology and Management. 170: 233-247.

Hanula, J.L.; Wade, D.D. 2003. Influence of long-term dormant-season burning and fire exclusion on ground-dwelling arthropod populations in longleaf pine flatwood ecosystems. Forest Ecology and Management. 175: 163-184.

Hay, D.B.; Guntert, M. 1983. Seasonal selection of tree cavities by pygmy nuthatches based on cavity characteristics. In: Snag habitat management: proceedings of the symposium. Gen. Tech. Rep. RM-GTR-99. Fort Collins, CO: U.S. Department of Agriculture, Forest Service, Rocky Mountain Research Station: 19-23.

Hayes, J.L.; Daterman, G.E. 2001. Bark beetles (Scolytidae) in eastern Oregon and Washington. Northwest Science. 75: 21-30.

Hayes, J.P.; Chan, S.S.; Emmingham, W.H.; Tappeiner, J.C.; Kellogg, L.D.; Bailey, J.D. 1997. Wildlife response to thinning young forests in the Pacific Northwest. Journal of Forestry. 95: 28-33.

Healthy Forest Restoration Act of 2003; 16 U.S.C. 6501 et seq. Public Law 108-148.

Heatwole, H. 1962. Relation of substrate moisture to absorption and loss of water by the salamander Plethodon cinereus. Ecology. 42: 814-819.

Heatwole, H. 1977. Habitat selection in reptiles. In: Gans, C.; Tinkle, D.W., eds. Biology of the reptilia. Vol. 7. Ecology and behaviour. New York: Academic Press: 137-155.

Hejl, S.J.; Mack, D.E.; Young, J.S.; Bednarz, J.C.; Hutto, R.L. 2002. Birds and changing landscape patterns in conifer forests of the north-central Rocky Mountains. Studies in Avian Biology. 25: 113-129.
Hobbs, N.T.; Spowart, R.A. 1984. Effects of prescribed fire on nutrition of mountain sheep and mule deer during winter and spring. Journal of Wildlife Management. 48: 551-560.

Hohenlohe, P.A.; Duncan, N. 2003. How do terrestrial mollusk populations survive fire? Northwest Naturalist. 84: 102. Abstract.

Horton, J. 1929. Birds and animals killed by forest fires. The Murrelet. 6: 22.

Horton, S.P.; Mannan, W.R. 1988. Effects of prescribed fire on snags and cavity-nesting birds in southeastern Arizona pine forests. Wildlife Society Bulletin. 16: 37-44.

Huff, M.H.; Seavy, N.E.; Alexander, J.D.; Ralph, C.J. 2005. Fire and Birds of the Maritime Pacific Northwest. Studies in Avian Biology. 30: 46-62.

Huffman, D.W.; Moore, M.M. 2003. Ungulate herbivory on buckbrush in an Arizona ponderosa pine forest. Journal of Range Management. 56: 358-363.

Huffman, D.W.; Moore, M.M. 2004. Responses of Fendler ceanothus to overstory thinning, prescribed fire, and drought in an Arizona ponderosa pine forest. Forest Ecology and Management. 198: 105-115.

Humes, M.L.; Hayes, J.P.; Collopy, M.W. 1999. Bat activity in thinned, unthinned, and old-growth forests in western Oregon. Journal of Wildlife Management. 63: 553-561.

Huntzinger, M. 2003. Effects of fire management practices on butterfly diversity in forested Western United States. Biological Conservation. 113: 1-12.

Huxel, G.R.; Hastings, A. 1999. Habitat loss, fragmentation, and restoration. Restoration Ecology. 7: 309-315.

Jain, T.B.; Pilliod, D.S.; Graham, R.T. 2004. Tongue-tied. Wildfire Magazine. July/August: 22-26.

James, S.E.;M'Closkey, R.T. 2003. Lizard microhabitat and fire fuel management. Biological Conservation. 114: 293-297.

Jennes, J.S. 2000. The effects of fire on Mexican spotted owls in Arizona and New Mexico. Flagstaff, AZ: Northern Arizona University. 129 p. Thesis.

Johnson, A.S.; Landers, J.L. 1978. Fruit production in slash pine plantations in Georgia. Journal of Wildlife Management. 42: 606-613.

Keay, J.A.; Peek, J.M. 1980. Relationship between fires and winter habitat of deer in Idaho. Journal of Wildlife Management. 44: 372-380.

Keith, L.B.; Surrendi, P.C. 1971. Effects of fire on a snowshoe hare population. Journal of Wildlife Management. 35: $16-26$.

King, T.G.; Howell, M.A.; Chapman, B.R.; Miller, K.V.; Schorr, R.A. 1998. Comparisons of wintering bird communities in mature pine stands managed by prescribed burning. Wilson Bulletin. 110: 570-574.

Kirkland, G.L., Jr.; Snoddy, H.W.; Amsler, T.L. 1996. Impact of fire on small mammals and amphibians in a central Appalachian deciduous forest. American Midland Naturalist. 135: 253-260. 
Knox, S.C.; Chambers, C.; Germaine, S.S. 2001. Habitat associations of the sagebrush lizard (Sceloporus graciosus): potential responses of an ectotherm to ponderosa pine forest restoration treatments. In: Vance, R.K.; Edminster, C.B.; Carleton, B; Covington, W.W.; Blake, J., comps. Ponderosa pine ecosystems restoration and conservation: steps toward stewardship. Proc. RMRS-P-22. Ogden, UT: U.S. Department of Agriculture, Forest Service, Rocky Mountain Research Station: 95-98.

Koehler, G.M.; Hornocker, M.G. 1977. Fire effects on marten habitat in the Selway-Bitterroot wilderness. Journal of Wildlife Management. 41: 500-505.

Komarek, E.E. 1969. Fire and animal behavior. In: Proceedings, annual Tall Timbers fire ecology conference; 1969 April 10-11. Tallahassee, FL: Tall Timbers Research Station. 9: 160-207.

Kotliar, N.B.; Hejl, S.J.; Hutto, R.L.; Saab, V.A.; Melcher, C.P.; McFadzen, M.E. 2002. Effects of fire and post-fire salvage logging on avian communities in conifer-dominated forests of the Western United States. Studies in Avian Biology. 25: 49-64.

Kramp, B.A.; Patton, D.R.; Brady, W.W. 1983. The effects of fire on wildlife habitat and species. Wildlife Unit Technical Report. Albuquerque, NM: U.S. Department of Agriculture, Forest Service, Southwestern Region. 29 p.

LaBonte, J.R.; Scott, D.W.; McIver, J.; Hayes, J.L. 2001. Threatened, endangered, and sensitive insects in eastern Oregon and Washington forests and adjacent lands. Northwest Science. 75: 185-198.

Lassau, S.A.; Hochuli, D.F. 2004. Effects of habitat complexity on ant assemblages. Ecography. 27: 157-164.

Lassau, S.A.; Hochuli, D.F.; Cassis, G.; Reid, C.A.M. 2005. Effects of habitat complexity on forest beetle diversity: do functional groups respond consistently? Diversity and Distribution. 11: 73-82.

Lehmkuhl, J.F.; Gould, L.E.; Cazares, E.; Hosford, D.R. 2004. Truffle abundance and mycophagy by northern flying squirrels in eastern Washington forests. Forest Ecology and Management. 200: 49-65.

Lehmkuhl, J.F.; Kistler, K.D.; Begley, J.S. 2006. Bushy-tailed woodrat abundance in dry forests of eastern Washington. Journal of Mammalogy. 87(2): 371-379.

Lehmkuhl, J.F.; Kistler, K.D.; Begley, J.S.; Boulanger, J. 2006. Demography of northern flying squirrels informs ecosystem management of Western interior forests. Ecological Applications. 16: 584-600.

Lillybridge, R.; Kovalchik, B.; Williams, C.; Smith, B.G. 1995. Field guide for forested plant associations of the Wenatchee National Forest. Gen. Tech. Rep. PNW-GTR359. Portland, OR: U.S. Department of Agriculture, Forest Service, Pacific Northwest Research Station. 335 p.

Lillywhite, H.B. 1977. Animal responses to fire and fuel management in chaparral. In: Mooney, H.A.; Conrad, E.C., eds. Proceedings of the symposium on environmental consequences of fire and fuel management in Mediterranean ecosystems. Gen. Tech. Rep. WO-GTR-3.
Washington, DC: U.S. Department of Agriculture, Forest Service: $368-272$.

Lillywhite, H.B.; Friedman, G.; Ford, N. 1977. Color matching and perch selection by lizards in recently burned chaparral. Copeia. 1977(1): 115-121.

Lillywhite, H.B.; North, F. 1974. Perching behavior of Sceloperus occidentalis in recently burned chaparral. Copeia. 1974: 256-257.

Litt, A.R.; Provencher, L.; Tanner, G.W.; Franz, R. 2001. Herpetofaunal responses to restoration treatments of longleaf pine sandhills in Florida. Restoration Ecology. 9: 462-474.

Lyon, L.J.; Crawford, H.S.; Czuhai, E.; Fredriksen, R.L.; Harlow, F.; Metz, L.J.; Pearson, H.A. 1978. Effects of fire on fauna: a state-of-knowledge review. Gen. Tech. Rep. WO-GTR-6. Washington, DC: U.S. Department of Agriculture, Forest Service. 22 p.

Machmer, M. 2002. Effects of ecosystem restoration treatments on cavity-nesting birds, their habitat, and their insectivorous prey in fire-maintained forests of southeastern British Columbia. In: Proceedings of the symposium of the ecology and management of dead wood in Western forests. Gen. Tech. Rep. PSW-GTR-181. Albany, CA: U.S. Department of Agriculture, Forest Service, Pacific Southwest Research Station: 121-133.

Main, M.B.; Richardson, L.W. 2002. Response of wildlife to prescribed fire in southwest Florida pine flatwoods. Wildlife Society Bulletin. 30: 213-221.

Mantgem, P.V.; Schwartz, M.; Keifer, M. 2001. Monitoring fire effects for managed burns and wildfires: coming to terms with pseudoreplication. Natural Areas Journal. 21: 266-273.

Martin, K.A.; McComb, B.C. 2003. Amphibian habitat associations at patch and landscape scales in western Oregon. Journal of Wildlife Management. 67: 672-683.

Mason, A.C.; Adams, D.L. 1989. Black bear damage to thinned timber stands in northwest Montana. Western Journal of Applied Forestry. 4: 10-13.

Master, L.L. 1991. Assessing threats and setting priorities for conservation. Conservation Biology. 5: 559-563.

Masters, R.E.; Lochmiller, R.L.; McMurry, S.T.; Bukenhofer, G.A. 1998. Small mammal response to pine-grassland restoration for red-cockaded woodpeckers. Wildlife Society Bulletin. 26: 148-158.

Mattson, T.A.; Buskirk, S.W.; Stanton, N.L. 1996. Roost sites of the silver-haired bat (Lasionycteris noctivagans) in Black Hills of South Dakota. Great Basin Naturalist. 56: 247-253.

McClelland, B.R.; Frissell, S.S.; Fischer, W.C.; Halvorson, C.H. 1979. Habitat management for hole-nesting birds in forest of western larch and Douglas-fir. Journal of Forestry. 77: 480-483.

McConnell, B.R.; Smith, J.G. 1970. Response of understory vegetation to ponderosa pine thinning in eastern Washington. Journal of Range Management. 23: 208-212. 
McCullough, D.G.; Werner, R.A.; Neumann, D. 1998. Fire and insects in northern and boreal forest ecosystems of North America. Annual Review of Entomology. 43: 107-127.

McGraw, R.L. 1997. Timber harvest effects on breeding and larval success of long-toed salamanders (Ambystoma macrodactylum). Missoula: University of Montana. Thesis.

McHugh, C.W.; Kolb, T.E.; Wilson, J.L. 2003. Bark beetle attacks on ponderosa pine following fire in northern Arizona. Environmental Entomology. 32: 510-522.

McIver, J.D. ; Parsons, G.L.; Moldenke, A.R. 1992. Litter spider succession after clear-cutting in a western coniferous forest. Canadian Journal of Forest Research 22: 984-992.

McLeod, R.F.; Gates, J.E. 1998. Response of herpetofaunal communities to forest cutting and burning at Chesapeake Farms, Maryland. American Midland Naturalist. 139: 164-177.

Means, D.B.; Campbell, H.W. 1981. Effects of prescribed burning on amphibians and reptiles. In: Wood, G.D., ed. Prescribed fire and wildlife in southern forests. Georgetown, SC: Clemson University, The Belle W. Baruch Forest Science Institute: 89-96.

Means, D.B.; Dodd, C.K.; Johnson, S.A.; Palis, J.G. 2004. Amphibians and fire in longleaf pine ecosystems: response to Schurbon and Fauth. Conservation Biology. 18: 1149-1153.

Medin, D.E.; Booth, G.D. 1989. Responses of birds and small mammals to single-tree selection logging in Idaho. Res. Pap. INT-RP-408. Ogden, UT: U.S. Department of Agriculture, Forest Service, Intermountain Research Station. 11 p.

Meyer, C.L.; Sisk, T.D.; Covington, W.W. 2001. Microclimatic changes induced by ecological restoration of ponderosa pine forests in northern Arizona. Restoration Ecology. 9: 443-452.

Meyer, M.D.; North, M.P.; Kelt, D.A. 2005. Short-term effects of fire and forest thinning on truffle abundance and consumption by Neotamias speciosus in the Sierra Nevada of California. Canadian Journal Forest Research. 35: 1061-1070.

Michael, E.D.; Thornburgh, P.I. 1971. Immediate effects of hardwood removal and prescribed burning on bird populations. The Southwestern Naturalist. 15: 359-379.

Miller, W.E. 1979. Fire as an insect management tool. Bulletin of Entomological Society of America. 25: 137-140.

Mollohan, C.; Brady, W.W.; LeCount, A.L. 1989. Habitat use of an Arizona ponderosa pine-mixed conifer forest by female black bears. Western Journal of Applied Forestry. 4: 6-9.

Moreira, F.; Delgado, A.; Ferreira, S.; Borralho, R.; Oliveira, N.; Ináco, M.; Silva, J.S.; Rego, F. 2003. Effects of prescribed fire on vegetation structure and breeding birds in young Pinus pinaster stands of northern Portugal. Forest Ecology and Management. 184: 225-237.

Morris, M.G. 1975. Preliminary observations on the effects of burning on the Hemiptera (Homoptera and Auchenorhyncha) of limestone grassland. Biological Conservation. 7: 312-319.

Moseley, K.R.; Castleberry, S.B.; Schweitzer, S.H. 2003. Effects of prescribed fire on herpetofauna in bottomland hardwood forests. Southeastern Naturalist. 2: 475-486.
Muir, P.S.; Mattingly, R.L.; Tappeiner, J.C., Il; [and others]. 2002. Managing for biodiversity in young Douglas-fir forests of western Oregon. Biological Science Report USGS/BRD/ BSR-2002-0006. Corvallis, OR: U.S. Geological Survey, Forest and Rangeland Ecosystem Science Center. 76 p.

Mushinsky, H.R. 1985. Fire and the Florida sandhill herpetofaunal community: with special attention to responses of Cnemidophorus sexlineatus. Herpetologica. 41: 333-342.

Mushinsky, H.R.; Gibson, D.J. 1991. The influence of fire periodicity on habitat structure. In: Bell, S.S.; McCoy, E.D.; Mushinsky, H.R., eds. Habitat complexity: the physical arrangement of objects in space. New York: Chapman \& Hall: 237-259.

Mutch, R.W. 1970. Wildland fires and ecosystems - a hypothesis. Ecology. 51: 1046-1051.

National Environmental Policy Act of 1969 [NEPA]; 42 U.S.C. 651 et seq.

National Forest Management Act of 1976 [NFMA]; Act of October 22, 1976; 16 U.S.C. 1600.

Naughton, G.P.; Henderson, C.B.; Foresman, K.R.; McGraw, R.L., II. 2000. Long-toed salamanders in harvested and intact Douglas-fir forests of western Montana. Ecological Applications. 10: 1681-1689.

Niemela, J. 1999. Management in relation to disturbance in the boreal forest. Forest Ecology and Management. 155: 127-134.

Nitschke, C.R. 2005. Does forest harvesting emulate fire disturbance? A comparison of effects on selected attributes in coniferous-dominated headwater systems. Forest Ecology and Management. 214: 305-319.

Niwa, C.G.; Peck, R.W. 2002. Influence of prescribed fire on carabid beetle (Carabidae) and spiders (Araneae) assemblages in forest litter in southwestern Oregon. Environmental Entomology. 31: 785-796.

Niwa, C.G.; Peck, R.W.; Torgersen, R.T. 2001a. Soil, litter, and coarse woody debris habitats for arthropods in eastern Oregon and Washington. Northwest Science. 75: 141-148.

Niwa, C.G.; Sandquist, R.E.; Crawford, R.; Frest, T.J.; Griswold, T.; Hammond, P.; Ingham, E.; James, S.; Johannes, E.J.; Johnson, J.; Kemp, W.P.; LaBonte, J.; Lattin, J.D.; McIver, J.; McMillin, J.; Moldenke, A.; Moser, J.; Ross, D.; Schowalter, T.; Tepedino, V.; Wagner, M.R. 2001b. Invertebrates of the Columbia River basin assessment area. Gen. Tech, Rep. PNW-GTR-512. Portland, OR: U.S. Department of Agriculture, Forest Service, Pacific Northwest Research Station. 74 p.

Office of Management and Budget [OMB]. 2001. Data Quality Act. P.L.106-554, Sect. 515.

Oliver, W.W. 2000. Ecological research at the Blacks Mountain Experimental Forest in northeastern California. Gen. Tech. Rep. PSW-GTR-179. Albany, CA: U.S. Department of Agriculture, Forest Service, Pacific Southwest Research Station. 66 p.

Ormsbee, P.C.; McComb, W.C. 1998. Selection of day roosts by female long-legged myotis in the central Oregon Cascade Range. Journal of Wildlife Management. 62: 596-603. 
Panzer, R. 2003. Importance of in situ survival, recolonization, and habitat gaps in postfire recovery of fire-sensitive prairie species. Natural Areas Journal. 23: 14-21.

Parks, C.G.; Conklin, D.A.; Bednar, L.; Maffei, H. 1999. Woodpecker use and fall rates of snags created by killing ponderosa pine infected with dwarf mistletoe. Res. Pap. PNW-RP-515. Portland, OR: U.S. Department of Agriculture, Forest Service, Pacific Northwest Research Station. 11 p.

Parks, C.G.; Radosevich, S.R.; Anzinger, D.; Maxwell, B.; Rew, L.; Dwire, K.A.; Endress, B.A. 2005. Natural and land-use history of the Northwest mountain ecoregions (USA) in relation to patterns of plant invasions. Perspectives in Plant Ecology, Evolution and Systematics. 7: 137-158.

Passovoy, M.D.; Fule, P.Z. 2006. Snag and woody debris dynamics following severe wildfires in northern Arizona ponderosa pine forests. Forest Ecology and Management. 223: 237-246.

Patriquin, K.J.; Barclay, R.M.R. 2003. Foraging by bats in cleared, thinned and unharvested boreal forest. Journal of Applied Ecology. 40: 646-657.

Patterson, G.B. 1984. The effect of burning-off tussock grassland on the population density of common skinks. New Zealand Journal of Zoology. 11: 189-194.

Peck, R.W.; Niwa, C.G. 2004. Longer-term effects of selective thinning on carabid beetle and spiders in the Cascade Mountains of southern Oregon. Northwest Science. 78: 267-277.

Perkins, J.M.; Cross, S.P. 1988. Differential use of some coniferous forest habitats by hoary and silver-haired bats in Oregon. Murrelet. 69: 21-24.

Peterson, D.L.; Johnson, M.C.; Agee, J.K.; Jain, T.B.; McKenzie, D.; Reinhardt, E.D. 2005. Forest structure and fire hazard in dry forests of the western United States. Gen. Tech. Rep. PNW-GTR-628. Portland, OR: U.S. Department of Agriculture, Forest Service, Pacific Northwest Research Station. 29 p.

Pilliod, D.S.; Bury, R.B.; Hyde, E.J.; Pearl, C.A.; Corn, P.S. 2003. Fire and amphibians in North America. Forest Ecology and Management. 178: 163-181.

Pilliod, D.S.; Shick, K.; Velasquez, M.E. [In press]. The wildlife habitat response model: Estimating terrestrial wildlife habitat responses to fuel treatments. In: Sutherland, E.K.; Black, A.E., eds. Estimating environmental consequences of fuels treatments: User's Guide. Gen. Tech. Rep. Fort Collins, CO: U.S. Department of Agriculture, Forest Service, Rocky Mountain Research Station.

Pollet, J.; Omi, P.N. 2002. Effect of thinning and prescribed burning on crown fire severity in ponderosa pine forests. International Journal of Wildland Fire. 11: 1-10.

Potter, M.W.; Kessell, S.R. 1980. Predicting mosaics and wildlife diversity resulting from fire disturbance to a forest ecosystem. Environmental Management. 4: 247-254.

Pough, F.H.; Andrews, R.M.; Cadle, J.E.; Crump, M.L.; Savitsky, A.H.; Wells, K.D. 2004. Herpetology, $3^{\text {rd }}$ ed. Upper Saddle River, NJ: Pearson Prentice Hall. 726 p.
Pough, F.H.; Smith, E.M.; Rhodes, D.H.; Collazo, A. 1987. The abundance of salamanders in forest stands with different histories of disturbance. Forest Ecology and Management. 20: 1-9.

Provencher, L.; Cobris, N.M.; Brennan, L.A.; Gordon, D.R.; Hardesty, J.F. 2002. Breeding bird response to midstory hardwood reduction in Florida sandhill longleaf pine forests. Journal of Wildlife Management. 66: 641-661.

Rabe, M.J.; Morrell, T.E.; Green, H.; deVos, J.C., Jr.; Miller, C.R. 1998. Characteristics of ponderosa pine snag roosts used by reproductive bats in northern Arizona. Journal of Wildlife Management. 62: 612-621.

Randall-Parker, T.; Miller, R. 2002. Effects of prescribed fire on ponderosa pine key wildlife habitat components: preliminary results and a method for monitoring. Gen. Tech. Rep. PSW-GTR-181. Berkeley, CA: U.S. Department of Agriculture, Forest Service, Pacific Southwest Research Station: 823-834.

Ream, C.H. 1981. The effects of fire and other disturbances on small mammals and their predators: an annotated bibliography. Gen. Tech. Rep. INT-GTR-106. Ogden, UT: U.S. Department of Agriculture, Forest Service, Intermountain Forest and Range Experiment Station. 55 p.

Reich, R.M.; Joy, S.M.; Reynolds, R.T. 2004. Predicting the location of northern goshawk nests: modeling the spatial dependency between nest locations and forest structure. Ecological Modeling. 176: 109-133.

Reynolds, H.G. 1962. Effect of logging on understory vegetation and deer use in ponderosa pine forest of Arizona. Research Notes 80. Fort Collins, CO: U.S. Department of Agriculture, Forest Service, Rocky Mountain Forest and Range Experiment Station. 7 p.

Reynolds, R.T.; Graham, R.T.; Reiser, M.H. 1992. Management recommendations for the northern goshawk in the Southwestern United States. Gen. Tech. Rep. RM-GTR217. Fort Collins, CO: U.S. Department of Agriculture, Forest Service, Rocky Mountain Forest and Range Experiment Station. $90 \mathrm{p}$.

Riggs, R.A.; Bunting, S.C.; Daniels, S.E. 1996. Prescribed fire. In: Krausman, P.R., ed. Rangeland wildlife. Denver, CO: The Society for Range Management: 295-319.

Robichaud, P.R. 2000. Fire effects on infiltration rates after prescribed fire in Northern Rocky Mountain forests, USA. Journal of Hydrology. 231-232: 220-229.

Robichaud, P.R.; Waldrop, T.A. 1994. A comparison of surface runoff and sediment yields from low- and high-severity site preparation burns. Water Resources Bulletin. 30: 27-34.

Ross, D. 1995. Short-term impacts of thinning ponderosa pine on pandora moth densities, pupal weights, and phenology. Western Journal of Applied Forestry. 10: 91-94.

Rudolph, D.C.; Conner, R.N.; Schaefer, R.R. 2002. Red-cockaded woodpecker foraging behavior in relation to midstory vegetation. Wilson Bulletin. 114: 235-242.

Russell, K.R.; Van Lear, D.H.; Guynn, D.C., Jr. 1999. Prescribed fire effects on herpetofauna: review and management implications. Wildlife Society Bulletin. 27: 374-384. 
Saab, V.A.; Dudley, J. 1998. Responses of cavity-nesting birds to stand-replacement fire and salvage logging in ponderosa pine/Douglas-fir forests of southwestern Idaho. Res. Pap. RMRS-RP-11. Fort Collins, CO: U.S. Department of Agriculture, Forest Service, Rocky Mountain Research Station. 17 p.

Saab, V.A.; Brannon, R.; Dudley, J.; Donohoo, L.; Vanderszanden, D.; Johnson, V.; Lachowski, H. 2002. Selection of fire-created snags at two spatial scales by cavity-nesting birds. In: Shea, P.J.; Laudenslayer, W.F., Jr.; Valentine, B.; Weatherspoon, C.P.; Lisle, T.E., eds. Proceedings of the symposium on the ecology and management of dead wood in western forests; 1999 November 2-4; Reno, NV. Gen. Tech. Rep. PSW-GTR-181. Albany, CA: U.S. Department of Agriculture, Forest Service, Pacific Southwest Research Station: 835-848.

Saab, V.A.; Dudley, J.; Thompson, W.L. 2004. Factors influencing occupancy of nest cavities in recently burned forests. The Condor. 106: 20-36.

Saab, V.A.; Powell, H.D.W. 2005. Fire and avian ecology in North America: process influencing pattern. Studies in Avian Biology. 30: 1-30.

Saab, V.A.; Powell, H.D.W.; Kotliar, N.B.; Newlon, K.R. 2005. Variation in fire regimes of the Rocky Mountains: implications for avian communities and fire management. Studies in Avian Biology. 30: 76-96.

Saab, V.A.; Vierling, K.T. 2001. Reproductive success of Lewis's woodpecker in burned pine and cottonwood riparian forests. The Condor. 103: 491-501.

Sanchez-Martinez, G.; Wagner, M.R. 2002. Bark beetle community structure under four ponderosa pine forest stand conditions in northern Arizona. Forest Ecology and Management. 170: 145-160.

Sanders, N. 2004. Immediate effects of fire on the invasive Argentine ant, Linepthema humile. The Southwestern Naturalist. 49: 246-250.

Schmidt, C.A. 2003. Conservation assessment for the silverhaired bat in the Black Hills National Forest South Dakota and Wyoming. Custer, SD: U.S. Department of Agriculture, Forest Service, Rocky Mountain Region, Black Hills National Forest. 22 p.

Schurbon, J.M.; Fauth, J.E. 2003. Effects of prescribed burning on amphibian diversity in a southeastern U.S. National Forest. Conservation Biology. 17: 1338-1349.

Schurbon, J.M.; Fauth, J.E. 2004. Fire as friend and foe of amphibians: a reply. Conservation Biology. 18: 1156-1159.

Scott, V.E.; Oldemeyer, J.L. 1983. Cavity-nesting bird requirements and response to snag cutting in ponderosa pine. In: Davis, J.W.; Goodwin, G.A.; Ockenfels, R.A., tech. coords. Snag habitat management: proceedings of the symposium. Gen. Tech. Rep. RM-GTR-99. Fort Collins, CO: U.S. Department of Agriculture, Forest Service, Rocky Mountain Forest and Range Experiment Station: 19-23.

Semlitsch, R.D. 2000. Principles for management of aquaticbreeding amphibians. Journal of Wildlife Management. 64: 615-631.
Setser, K.; Cavitt, J.F. 2003. Effects of burning on snakes in Kansas, USA, tallgrass prairie. Natural Areas Journal. 23: 315-319.

Shick, K. 2003. The influence of stand-level vegetation and landscape composition on the abundance of snowshoe hares (Lepus americanus) in managed forest stands in western Montana. Missoula: University of Montana. 102 p. Thesis.

Sort, K.C.; Negron, J.F. 2003. Arthropod responses: a functional approach. In: Friederici, P., ed. Ecological restoration of Southwestern ponderosa pine forests. Washington, DC: Island Press: 286-305.

Simon, N.P.P.; Schwab, F.E.; Diamond, A.W. 2000. Patterns of breeding bird abundance in relation to logging in western Labrador. Journal of Forest Research. 30: 257-263

Singh, S.; Smyth, A.K.; Blomberg, S.P. 2002. Effect of a control burn on lizards and their structural environment in a eucalypt open-forest. Wildlife Research. 23: 447-454.

Six, D.L.; Vander Meer, M.; DeLuca, T.H.; Kolb, P. 2002. Pine engraver (Ips pini) colonization of logging residues created using alternative slash management systems in western Montana. Western Journal of Applied Forestry. 17: 96-100.

Smith, J.K., ed. 2000. Wildland fire in ecosystems: effects of fire on fauna. Gen. Tech. Rep. RMRS-GTR-42 Vol. I. Fort Collins, CO: U.S. Department of Agriculture, Forest Service, Rocky Mountain Research Station. 83 p.

Spildie, D.R.; Stanton, N.L.; Buskirk, S.W. [n.d.] Post-fire succession of small mammals in montane forests of the greater Yellowstone area, Wyoming. Unpublished paper on file at: U.S. Department of Agriculture, Forest Service, Rocky Mountain Research Station, Aldo Leopold Wilderness Research Institute, Missoula, MT. 41 p.

Springett, J.A. 1976. The effect of prescribed burning on the soil fauna and on litter decomposition in Western Australian forests. Australian Journal of Ecology. 1: 77-82.

Squires, J.R.; Reynolds, R.T. 1997. Northern goshawk (Accipiter gentiles). In: Poole, A.; Gill, F., eds. The Birds of North America No. 298. Philadelphia, PA: The Academy of Natural Sciences; Washington, DC: American Ornithologists' Union.

Steventon, J.D.; MacKenzie, K.L.; Mahon, T.E. 1998. Response of small mammals and birds to partial cutting and clearcutting in northwest British Columbia. The Forestry Chronicle. 74: 703-713.

Sullivan, B.T.; Fettig, C.J.; Otrosina, W.J.; Dalusky, M.J.; Berisford, C.W. 2003. Association between severity of prescribed burns and subsequent activity of conifer-feeding beeltes in stands of longleaf pine. Forest Ecology and Management. 185: 327-340.

Sullivan, T.P.; Sullivan, D.S. 1988. Influence of stand thinning on snowshoe hare population dynamics and feeding damage in lodgepole pine forest. Journal of Applied Ecology. 25: 791-805.

Sullivan, T.P.; Sullivan, D.S.; Lindgren, P.M.F. 2001. Stand structure and small mammals in young lodgepole pine forest: 10-year results after thinning. Ecological Applications. 11: 1151-1173. 
Taylor, D.L.; Barmore, W.J. 1980. Post-fire succession of avifauna in coniferous forests of Yellowstone and Grand Teton National Parks, Wyoming. In: Management of Western forests and grasslands for nongame birds: workshop proceedings. Gen. Tech. Rep. INT-GTR-86. Ogden, UT: U.S. Department of Agriculture, Forest Service, Intermountain Research Station: 130-145.

Thomas, D.W. 1988. The distribution of bats in different ages of Douglas-fir forests. Journal of Wildlife Management. 52: 619-626.

Trainor, C.R.; Woinarski, J.C.Z. 1994. Responses of lizards to three experimental fires in the Savanna Forests of Kakadu National Park. Wildlife Research. 21: 131-148.

U.S. Department of Agriculture; U.S. Department of the Interior; Western Governors Association. 2001. A collaborative approach for reducing wildland fire risks to communities and the environment: 10-year comprehensive strategy. $21 \mathrm{p}$.

U.S. Department of Agriculture. 2003. A strategic assessment of forest biomass and fuel reduction treatments in western states. Washington, DC: U.S. Department of Agriculture, Forest Service. $18 \mathrm{p}$.

U.S. Department of Agriculture. 2005. National Forest Management Act, Planning Rule.

Villa-Castillo, J.; Wagner, M.R. 2002. Ground beetle (Coleoptera: Carabidae) species assemblages as an indicator of forest condition in northern Arizona ponderosa pine forests. Environmental Entomology. 31: 242-252.

Vonhof, M.J.; Barclay, R.M.R. 1996. Roost-site selection and roosting ecology of forest-dwelling bats in southern British Columbia. Canadian Journal of Zoology. 74: 1797-1805.

Vreeland, J.K.; Tietje, W.D. 2002. Numerical response of small vertebrates to prescribed fire in California oak woodland. In: Ford, W.M.; Russell, K.R.; Moorman, C.E., eds. The role of fire in nongame wildlife management and community restoration: traditional uses and new directions. Gen. Tech. Rep. NE-GTR-288. Newtown Square, PA: U.S. Department of Agriculture, Forest Service, Northeastern Research Station: 100-110.
Wallin, K.F.; Kolb, T.E.; Skov, K.R.; Wagner, M.R. 2003. Effects of crown scorch on ponderosa pine resistance to bark beetles in northern Arizona. Environmental Entomology. 32: 652-661.

Waltz, A.E.M.; Covington, W.W. 2004. Ecological restoration treatments increase butterfly richness and abundance: mechanisms of response. Restoration Ecology. 12: 85-96.

Wilson, C.W.; Masters, R.E.; Bukenhofer, G.A. 1995. Breeding bird response to pine-grassland community restoration for red-cockaded woodpeckers. Journal of Wildlife Management. 59: 56-67.

Wissmar, R.C.; Beschta, R.L. 1998. Restoration and management of riparian ecosystems: a catchment perspective. Freshwater Biology. 40: 571-585.

Witcosky, J.J. 1986. The influence of time of precommerical thinning on the colonization of Douglas-fir (Pseudotsuga menziesii) by three species of root-colonizing insects. Canadian Journal Forest Research. 16: 745-749.

Woolf, J. 2003. The effects of thinning and prescribed fire on birds, small mammals, and avian species composition. Missoula: University of Montana. 93 p. Thesis.

Zabowski, D.; Java, B.; Scherer, G.; Everett, R.L.; Ottmar, R. 2000. Timber harvesting residue treatment: Part 1. Response of conifer seedlings, soils, and microclimate. Forest Ecology and Management. 126: 25-34.

Zack, S.; George, T.L.; Laudenslayer, W.F., Jr. 2002. Are there snags in the system? Comparing cavity use among nesting birds in "snag-rich" and "snag-poor" eastside pine forests. Gen. Tech. Rep. PSW-GTR-181. Berkeley, CA: U.S. Department of Agriculture, Forest Service, Pacific Southwest Research Station: 179-191.

Zettler, J.A.; Taylor, M.D.; Allen, C.R.; Spira, T.P. 2003. Consequences of forest clear-cuts for native and nonindigenous ants (Hymenoptera: Formicidae). Annals of the Entomological Society of America. 97: 513-518. 


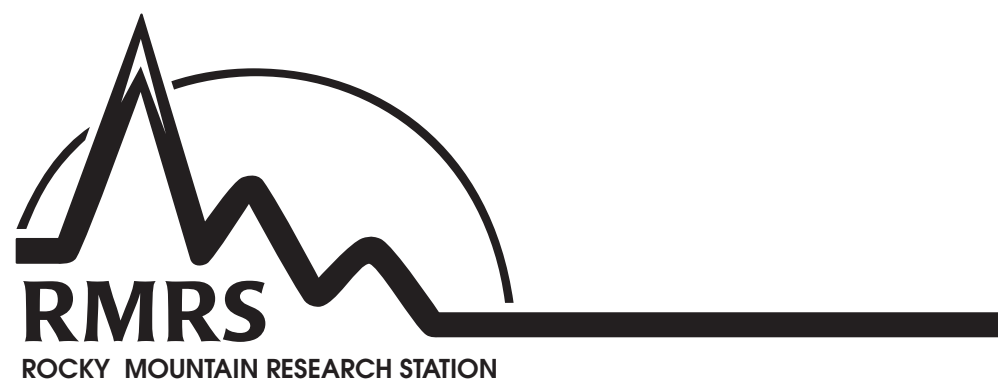

The Rocky Mountain Research Station develops scientific information and technology to improve management, protection, and use of the forests and rangelands. Research is designed to meet the needs of National Forest managers, Federal and State agencies, public and private organizations, academic institutions, industry, and individuals.

Studies accelerate solutions to problems involving ecosystems, range, forests, water, recreation, fire, resource inventory, land reclamation, community sustainability, forest engineering technology, multiple use economics, wildlife and fish habitat, and forest insects and diseases. Studies are conducted cooperatively, and applications may be found worldwide.

\section{Research Locations}

Flagstaff, Arizona

Fort Collins, Colorado*

Boise, Idaho

Moscow, Idaho

Bozeman, Montana

Missoula, Montana
Reno, Nevada

Albuquerque, New Mexico Rapid City, South Dakota

Logan, Utah

Ogden, Utah

Provo, Utah

*Station Headquarters, Natural Resources Research Center, 2150 Centre Avenue, Building A, Fort Collins, CO 80526

The U.S. Department of Agriculture (USDA) prohibits discrimination in all its programs and activities on the basis of race, color, national origin, age, disability, and where applicable, sex, marital status, familial status, parental status, religion, sexual orientation, genetic information, political beliefs, reprisal, or because all or part of an individual's income is derived from any public assistance program. (Not all prohibited bases apply to all programs.) Persons with disabilities who require alternative means for communication of program information (Braille, large print, audiotape, etc.) should contact USDA's TARGET Center at (202) 720-2600 (voice and TDD).

To file a complaint of discrimination, write to USDA, Director, Office of Civil Rights, 1400 Independence Avenue, S.W., Washington, DC 20250-9410, or call (800) 795-3272 (voice) or (202) 720-6382 (TDD). USDA is an equal opportunity provider and employer. 


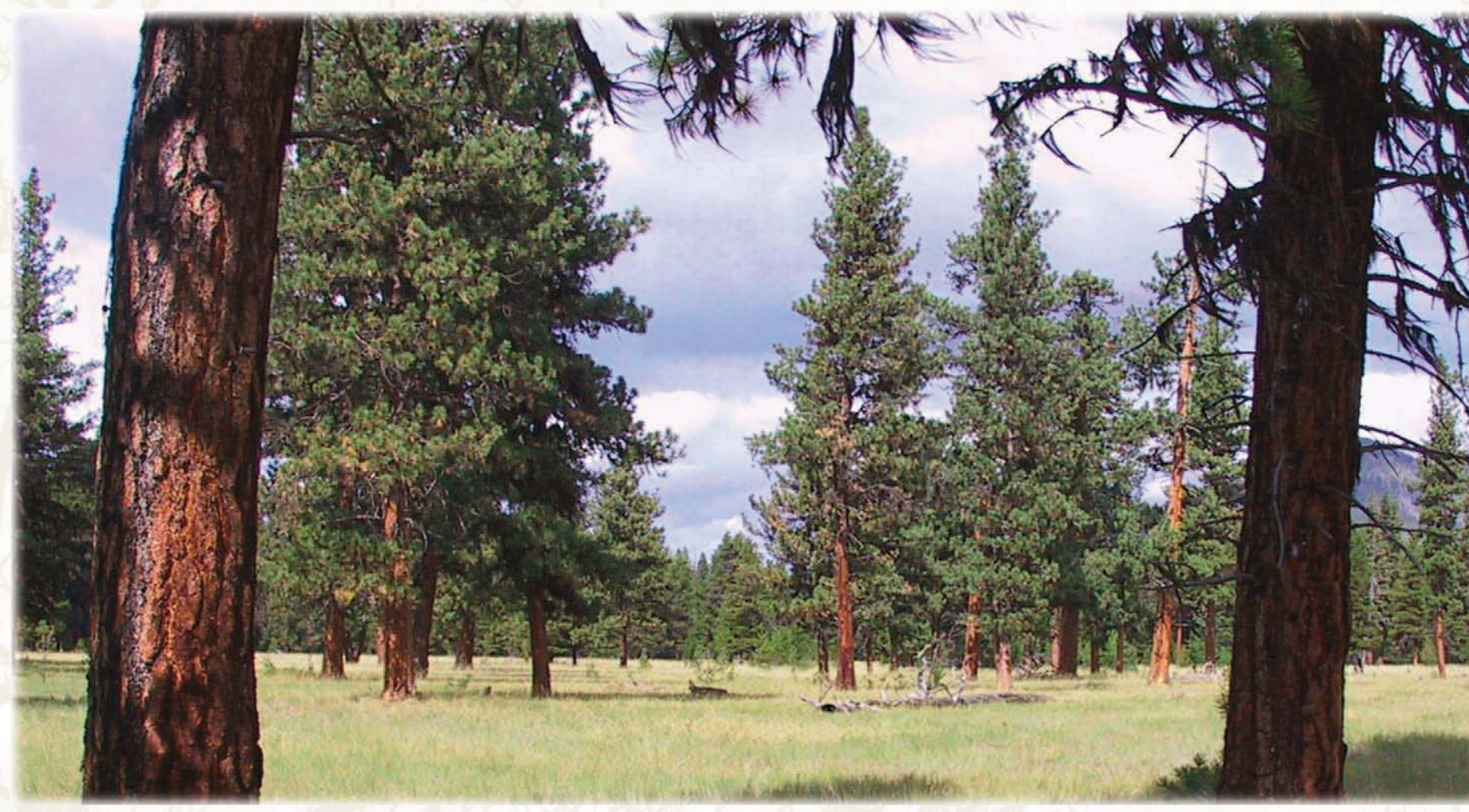

Sponsors:

United States Department of Agriculture Forest Service

North Central Research Station

Pacific Northwest Research Station

Pacific Southwest Research Station

Rocky Mountain Research Station 